\title{
The Little Ice Age history of the Glacier des Bossons (Mont Blanc massif, France): a new high-resolution glacier length curve based on historical documents
}

\author{
Samuel U. Nussbaumer · Heinz J. Zumbühl
}

Received: 25 June 2010 / Accepted: 27 May 2011 / Published online: 28 June 2011

(C) Springer Science+Business Media B.V. 2011

\begin{abstract}
Historical and proxy records document that there is a substantial asynchronous development in temperature, precipitation and glacier variations between European regions during the last few centuries. The causes of these temporal anomalies are yet poorly understood. Hence, highly resolved glacier reconstructions based on historical evidence can give valuable insights into past climate, but they exist only for few glaciers worldwide. Here, we present a new reconstruction of length changes for the Glacier des Bossons (Mont Blanc massif, France), based on unevaluated historical material. More than 250 pictorial documents (drawings, paintings, prints, photographs, maps) as well as written accounts have been critically analysed, leading to a revised picture of the glacier's history, especially from the mideighteenth century up to the 1860 s. Very important are the drawings by Jean-Antoine Linck, Samuel Birmann and Eugène Viollet-le Duc, which depict meticulously the glacier's extent during the vast advance and subsequent retreat during the nineteenth century. The new glacier reconstruction extends back to AD 1580 and proves maxima of the Glacier des Bossons around 1610/1643, 1685, 1712, 1777, 1818, 1854, 1892, 1921, 1941, and 1983. The Little Ice Age maximum extent was reached in 1818. Until the present, the glacier has lost about $1.5 \mathrm{~km}$ in length, and it is now shorter than at any time during the reconstruction period. The Glacier des Bossons reacts faster than the nearby Mer de Glace (glacier reconstruction back to AD 1570 available). The Mont Blanc area is, together with the valley of Grindelwald in the Swiss Alps (two historical glacier reconstructions available back to AD 1535, and 1590, respectively), among the two regions that are probably best-documented in the world regarding historical glacier data.
\end{abstract}

S. U. Nussbaumer $(\bowtie) \cdot$ H. J. Zumbühl

Institute of Geography and Oeschger Centre for Climate Change Research,

University of Bern, Bern, Switzerland

e-mail: samuel.nussbaumer@geo.uzh.ch

S. U. Nussbaumer

Department of Geography, University of Zurich, Zurich, Switzerland 


\section{Introduction}

Mountains and their environments are highly sensitive indicators of climate variability over decadal to centennial time scales. In particular, and corresponding to global trends in temperature, glaciers have retreated significantly since the mid-nineteenth century (e.g., Paul et al. 2004; Oerlemans 2005; IPCC 2007). By the year 2000, Alpine glaciers had lost almost $50 \%$ of their total area since 1850 , and a continuation or even acceleration of the glacier retreat may soon lead to conditions without historical or even Holocene comparability (Zemp et al. 2006). Detailed knowledge about past glacier variations allows assessing these ongoing changes. In this context, the understanding of the Little Ice Age (LIA), the period lasting a few centuries between the Middle Ages and the warming of the first half of the twentieth century (Pfister 1999; Grove 2004), is important.

Glaciers react sensitively to climate, which in turn is determined by external forcing factors as well as the internal variability of the system (Wanner et al. 2008). The glacier mass balance is mainly affected by winter precipitation and summer temperature (Oerlemans and Reichert 2000), but temperature and precipitation patterns in other seasons can be essential for particular glacier advances and retreats (Steiner et al. 2008a).

Surface mass balance directly reflects climatic variations. Glacier length on the other hand is an indirect, filtered and delayed signal of climate information (Oerlemans 2001). Glacier length fluctuations can easily be measured, and corresponding continuous records exist since the end of the nineteenth century (e.g., Gletscherberichte (1881-2009) for the Swiss Alps, Mougin (1912) for the Mont Blanc massif). It has been used to reconstruct glacier mass balance (Haeberli and Hoelzle 1995; Hoelzle et al. 2003) as well as large scale temperature changes over the last centuries (Oerlemans 2005). The available time series of glacier length are much longer than series of mass balance measurements (however, the first systematic mass balance measurements were performed at Rhonegletscher (Switzerland) already in the 1880s (Mercanton 1916), and reconstructions of glacier mass balance are available back to 1865 for selected glaciers in the Swiss Alps; Huss et al. 2008; Nemec et al. 2009). For the time period beyond the beginning of the first glacier length measurements, historical and geomorphological methods can be used to reconstruct past glacier behaviour.

Historical and proxy records document a partly asynchronous evolution in temperature, precipitation and glacier fluctuations between European regions during the LIA, and the causes of these temporal anomalies are yet poorly understood (Nesje and Dahl 2003; Wanner et al. 2008). To address this question, highly resolved glacier reconstructions going far back in time based on historical documents (e.g., Zumbühl 1980) or dendrochronological and radiocarbon dating (e.g., Holzhauser et al. 2005) may yield valuable insights into past climate.

Such reconstructions only exist for few glaciers worldwide, depending on the awareness level and the accessibility of the corresponding glacier and its surroundings. One of the regions of interest is the well-documented Mont Blanc massif. Pioneering (glaciological) studies (main focus on the north side of the Mont Blanc) have been performed by de Saussure (1779-1796), Forbes (1843), Viollet-le Duc (1876) and Vallot (1900). Later on, Paul Mougin published his comprehensive work "Etudes glaciologiques" (six volumes) from 1909-1934. A detailed description of the 
Mer de Glace and Glacier des Bossons (both on the northern flank of the Mont Blanc, France), among other glaciers, can be found in the third volume (Mougin 1912). Finally, the important work by Le Roy Ladurie (1967) gives an excellent overview of climate history and treats Alpine glaciers with historical evidence, such as the Mer de Glace and the Glacier des Bossons.

As there were only few historical documents used by Mougin (1912) to reconstruct glacier length changes, we present here a new and revised reconstruction highly resolved for the Glacier des Bossons back to AD 1580. Many of the historical documents collected (focus on pictorial documents from the mid-eighteenth century until about 1900) are newly available and unpublished so far. This task is completed by an analysis of the glacier foreland, based on the previous studies by Wetter (1987). The result obtained for the Glacier des Bossons is finally compared with the reconstructions of the nearby Mer de Glace (data back to AD 1570 available; Nussbaumer et al. 2007) and the two Grindelwald glaciers (Unterer and Oberer) in the Swiss Alps (data back to AD 1535, and 1590, respectively; Zumbühl 1980; Zumbühl et al. 1983).

\section{Study sites}

The Glacier des Bossons is a valley glacier $7.3 \mathrm{~km}$ long that is situated at the northern exposition of the Mont Blanc (French Alps). It descends in an unbroken continuity of ice from the very summit of Mont Blanc (4808 $\mathrm{m}$ asl.) down to the valley of Chamonix (Figs. 1 and 2). Besides Mont Blanc, the glacier is encompassed by other famous

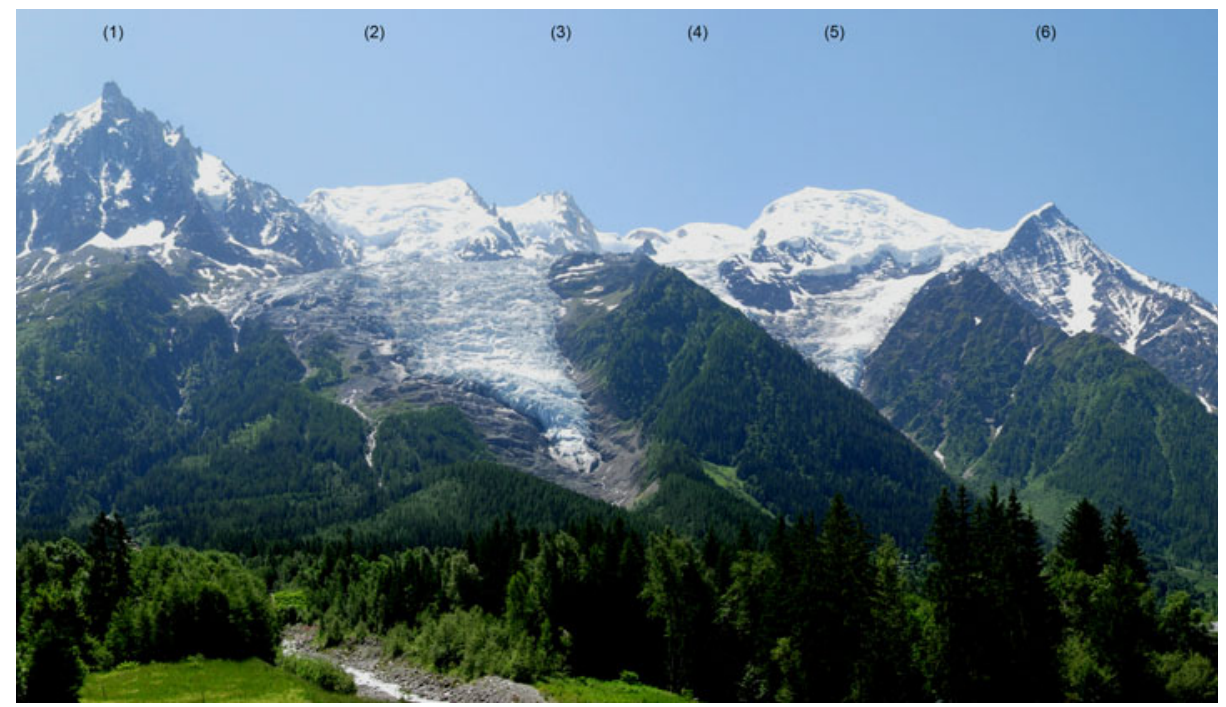

Fig. 1 Recent view of the Glacier des Bossons, with Aiguille du Midi (1), Mont Blanc du Tacul (2), Mont Maudit (3), Mont Blanc (4), Dôme du Goûter (5), and Aiguille du Goûter (6) in the background. The Glacier de Taconnaz can be seen below Dôme du Goûter, the glacier tongue is not visible (photograph by S. U. Nussbaumer, 17.06.2009) 


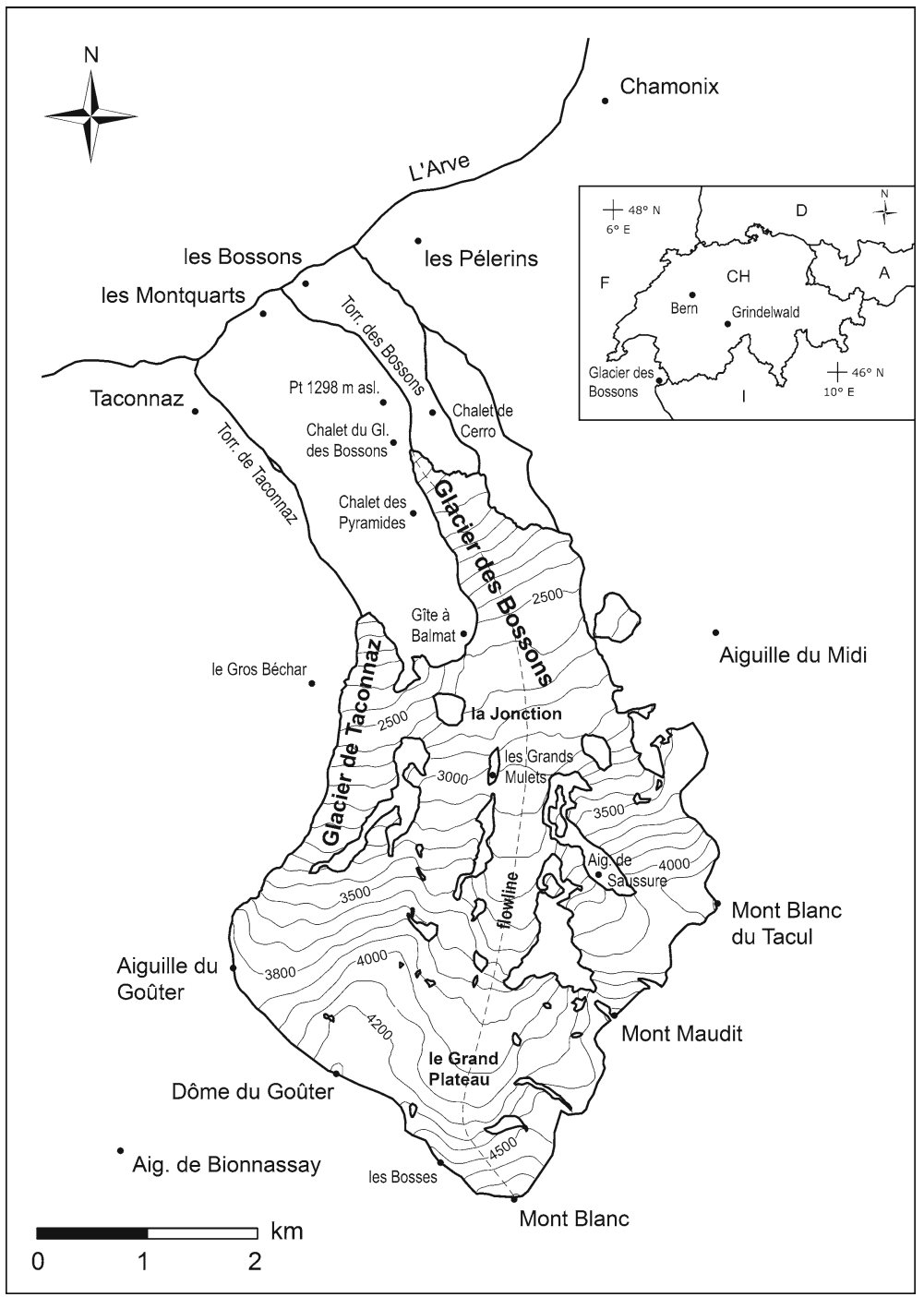

Fig. 2 Outline of the Glacier des Bossons as of 2001, and important geographical locations and mountain peaks

mountain peaks such as Dôme du Goûter, Mont Maudit or Mont Blanc du Tacul. The catchment area does not only feed the tongue of the Glacier des Bossons, but also a smaller branch situated to the west named Glacier de Taconnaz, with a tongue at higher elevation. The whole glacier system covers an area of about $14.6 \mathrm{~km}^{2}$ (Glacier des Bossons: $9.9 \mathrm{~km}^{2}$, Glacier de Taconnaz: $4.7 \mathrm{~km}^{2}$; all data for 2001). Table 1 shows a comparison of the glacier's characteristics with the Mer de Glace, situated next to the Glacier des Bossons valley-upwards, and with the two glaciers of Grindelwald in the Bernese Alps (Switzerland). Reconstructed glacier length changes of the Glacier des Bossons will be compared with existing reconstructions of those glaciers. 
Table 1 Topographical characteristics of the Glacier des Bossons in comparison with other Alpine glaciers with length reconstructions available back to the sixteenth century

\begin{tabular}{lllll}
\hline Name of glacier & $\begin{array}{l}\text { Glacier } \\
\text { des Bossons }\end{array}$ & Mer de Glace & $\begin{array}{l}\text { Unterer } \\
\text { Grindelwaldgletscher }\end{array}$ & $\begin{array}{l}\text { Oberer } \\
\text { Grindelwaldgletscher }\end{array}$ \\
\hline Coordinates & $45^{\circ} 53^{\prime} \mathrm{N}$, & $45^{\circ} 53^{\prime} \mathrm{N}$, & $46^{\circ} 34^{\prime} \mathrm{N}$, & $46^{\circ} 37^{\prime} \mathrm{N}$, \\
& $6^{\circ} 52^{\prime} \mathrm{E}$ & $6^{\circ} 56^{\prime} \mathrm{E}$ & $8^{\circ} 05^{\prime} \mathrm{E}$ & $8^{\circ} 06^{\prime} \mathrm{E}$ \\
Length [km] & 7.3 & 12.0 & 8.9 & 5.3 \\
Surface area [km $\left.{ }^{2}\right]$ & 9.9 & 31.9 & 20.6 & 9.2 \\
Head [m asl.] & 4,808 & 4,072 & 4,107 & 3,740 \\
& $($ Mont Blanc) & & $($ Mönch $)$ & 1,380 \\
Terminus [m asl.] & 1,420 & 1,467 & 1,297 & 24.0 \\
Average slope [ $\left.{ }^{\circ}\right]$ & 24.9 & 12.3 & 17.5 & 150 \\
Ice thickness [m] & 120 & 400 & 230 & 17 \\
Response time [a] & 9 & 41 & 22 &
\end{tabular}

Data: Glacier des Bossons: 2001 (this study); Mer de Glace: 2001 (Nussbaumer et al. 2007); Unterer Grindelwaldgletscher: 2004 (Steiner et al. 2008b); Oberer Grindelwaldgletscher: 2006 (this study). Ice thickness from Vivian (2001) and Linsbauer et al. (2009). Glacier response times were estimated according to Haeberli and Hoelzle (1995) and Hoelzle et al. (2007). Note that Schmeits and Oerlemans (1997) calculated a response time of 34-45 years for the Unterer Grindelwaldgletscher

During the LIA, the tongue of the Glacier des Bossons, named "Glacier des Buissons" ("buissons" = shrubbery in French) according to de Saussure (1786: 59), reached as far down as close to the hamlets les Montquarts and les Bossons, threatening people living there in the valley bottom. This fact led to the earliest descriptions of the glacier. With the beginning of the first journeys into the Alps for scientific and touristic purposes from the mid-eighteenth century on, the glacier soon became a desirable object of study for scientists, artists and tourists. This explains the large number of historical documentary data available for the Glacier des Bossons.

The Mont Blanc mountain range extends $50 \mathrm{~km}$ from Martigny (Switzerland) in the northeast to St. Gervais (France) in the southwest, forming the watershed between France and Italy and separating the uppermost catchment areas of the rivers Rhône and Po. On the French side of the mountain range, the upper Arve flows down the deep trough of Chamonix, with several glaciers (Glacier du Tour, Glacier d'Argentière, Mer de Glace, Glacier des Bossons) draining into this river.

Besides the glaciation of the elevated areas with its glacier tongues reaching far down into the valley, the geology contributes to the attractiveness of the area. Already the German poet Johann Wolfgang Goethe mentioned on his visit of the valley of Chamonix in late autumn 1779 the granitic rocks which extend towards the sky like nails. Moreover, the summit of Mont Blanc, consisting of an ice cap, is the highest point in Europe west of the Caucasus, forming the crown of the mountain massif.

The chain of Mont Blanc not only forms the watershed separating the catchment areas of Rhône and Po, but also marks the border between two completely different climate regions, the northern/western and the southern Alps. Climate in the valley of Chamonix is typical for the western Alps and comparable to the Grindelwald area, although slightly drier. The mean annual temperature of the Chamonix meteorological station (1054 $\mathrm{m}$ asl.) is $6.5^{\circ} \mathrm{C}$, the annual precipitation amounts to $1238 \mathrm{~mm}$ (1961-1990 period; data from Météo-France). 
Also for the Unterer and Oberer Grindelwaldgletscher, there is a wealth of historical documents (especially for the Unterer Grindelwaldgletscher). These glaciers are situated in the northern part of the Bernese Alps (Switzerland), exposed to the westerlies. The mean annual temperature at Grindelwald meteorological station (1040 m asl.), located approximately $3 \mathrm{~km}$ from the glacier front of the Unterer Grindelwaldgletscher, was $6.1^{\circ} \mathrm{C}$ during the $1966-1989$ period. Mean annual precipitation during the 1961-1990 period was $1427 \mathrm{~mm}$ (data from MeteoSwiss). Because of the high precipitation (locally exceeding 4,000 $\mathrm{mm}$ per year), the Bernese Alps show a relatively low glacier equilibrium line altitude (ELA) and are the mountain range showing the heaviest glaciation of the Alps. Both the glacier with the lowest front (Unterer Grindelwaldgletscher, though nowadays not dynamically active any more), and the largest glacier of the Alps (Grosser Aletschgletscher) are situated within this region (Kirchhofer and Sevruk 1992; Imhof 1998).

\section{Methods and data}

\subsection{Historical methods}

\subsubsection{Determination of glacier length changes for the LIA}

According to Zumbühl and Holzhauser (1988), the historical method, the glacioarchaeological method and the glacio-morphological method can be used to reconstruct glacier fluctuations before the start of systematic measurements. The historical method uses three main types of sources, namely cartographical documents (i.e., maps, cadastral plans, and reliefs), pictorial documents (i.e., drawings, paintings, prints, and photographs), and written accounts containing direct or indirect evidence of former glacier fluctuations (i.e., chronicles, church registers, land sale contracts, travel descriptions, early scientific works on Alpine research, and others). Examples for earliest glacier representations are known for the advancing Unterer Grindelwaldgletscher in the seventeenth century (etching by Joseph Plepp and Matthäus Merian, published in 1642; Zumbühl 1980), and even older for the Vernagtferner (eastern Alps) in 1601 (drawing, showing the Rofental with a lake dammed by the advancing glacier; Nicolussi 1990).

The glacio-archaeological method aims at finding evidence of former glacier extents by archaeological remains such as old trails, passes, foundations of destroyed buildings, or relics of water conduits. Dating is often possible with the help of literary sources or by means of dendrochronology or radiocarbon dating (Holzhauser et al. 2005). The glacio-morphological method, finally, comprises the mapping of the glacier foreland and the moraines found therein. Major glacier advances are reflected in moraines that are often still visible today. The age of moraines can be determined either with fossil soils, i.e. overwhelmed vegetation surfaces that can be dated with the radiocarbon method, or with fossil wood (trunks, rootstocks, roots, bushes) by means of dendrochronology or radiocarbon dating (e.g., Luckman et al. 1993; Nicolussi 1994; Holzhauser et al. 2005).

For the determination of length fluctuations of the Glacier des Bossons during the LIA, we evaluated historical sources and combined these findings with field evidence (existing moraines, in agreement with the previous studies of Mougin 1912, and 
Wetter 1987). The reconstruction of former glacier extents based on the evaluation of pictorial documents is described more in detail in the following.

\subsubsection{The evaluation of pictorial documents}

According to Zumbühl and Holzhauser (1988), three conditions have to be fulfilled in order to obtain reliable results concerning former glacier extents:

1. The dating of the pictorial document has to be known or reconstructed,

2. the glacier and its surroundings have to be represented realistically and topographically correctly (which implies certain qualities of the picture and skills of the corresponding author), and

3. the artist's position in the field should be known.

If some of the said requirements are not met, the glacier front position deduced from the document contains an uncertainty (i.e., if the exact location of the glacier terminus is not possible, a range of possible front positions is obtained). Hence, there is an error bar for each historical document that indicates the range of possible positions of the glacier tongue. For instance, an archive text from 1580 (see Section 4.1.1) states that the Glacier des Bossons "nearly reaches down to the plain". Taking the local topography into account, this gives us a possible range for the glacier front of $\pm 200 \mathrm{~m}$.

Note that especially for oil paintings it is important to distinguish between the time of the first draft in the field and the production of the painting itself later on. Some artists liked composing motifs of their own in the foreground or omitting unaesthetic frontal moraines. Although this is not always the case, the topographical accuracy usually increases with the artistic quality. The works of art have thus to pass a critical appraisal and only reliable documents have to be selected for interpretation. A photograph representing the glacier front is obviously very valuable, but additional information obtained by labour-intensive archive work is often needed to know the exact date of the photograph.

Pictorial documents are evaluated with the help of distinctive elements in the glacier's surroundings, such as rock steps or mountain peaks in the background. For pictorial document of high quality, this allows an exact location (georeferencing) of the artist's position. The location of the glacier front is then deduced using a geographic information system (determination of the angle of view, ensuring of the correct proportions). Note that the reconstruction of front positions and their dating is often based on multiple evidence.

\subsection{Historical data for the Mont Blanc area}

In Europe, the historical sources concerning glaciers are more plentiful than elsewhere (Grove 2004). The density of historical material prior to 1800 highly depends on the elevation of the glacier tongue and the threatening of settlements and cultivated land due to glacier advances (e.g., Le Roy Ladurie 1967). Information from travel descriptions started in the mid-eighteenth century and went on until the mid-nineteenth century, when they were replaced by the systematic glacier front measurements. Since the mid-nineteenth century, first photographs of glaciers are 
available, and together with modern cartography they constitute more accurate sources.

The historical (pictorial) material appears exceptionally rich for the Mont Blanc region and the Glacier des Bossons (more than 250 pictorial documents). This abundance is due to the fact that the glacier reached far down into the valley of Chamonix during the LIA. The glacier was an attractive object, either at the glacier snout, or when climbing Mont Blanc since the rise of alpinism. However, as archive material prior to the nineteenth century is not rare but often ambiguous and thus delicate for interpretation, the material had to be selected carefully according to the criteria mentioned in the previous section.

A wealth of documents newly discovered, from the 1770 s until about 1900 , has not been used for glacier reconstructions so far. Excellent examples of glacier representations of the Glacier des Bossons are the drawings by Jean-Antoine Linck (1766-1843), Samuel Birmann (1793-1847), and Eugène Viollet-le Duc (1814-1879). All three authors are very reliable, and they made exact representations of the glacier from several points of view, and in different years. Exceptionally well-documented is the year 1823, when Birmann documented the state of the glacier from different positions (this is also the case for the Mer de Glace; cf. Nussbaumer et al. 2007).

In Fig. 3, the summation of all historical sources that were evaluated to reconstruct length changes of the Glacier des Bossons is provided (for more details, see Appendix, Table 2). Note that there are many more (pictorial) documents of the glacier that could not be used due to missing dates or inaccuracies.

\section{Fluctuations of the Glacier des Bossons during the LIA and up to the present}

Figure 3 shows the cumulative length fluctuations of the Glacier des Bossons from 1580-2005. The position of the glacier front is plotted relative to the LIA maximum in 1818, measured along the flowline. The number, quality and character of the available historical documents determine the uncertainty for each data point (dashed lines). The curve is described in detail in the following section. Moraines mentioned in Fig. 3 are discussed in Section 4.2.

\subsection{History of the Glacier des Bossons as documented by historical sources}

\subsubsection{First descriptions of the glacier and cartographical documents from the sixteenth to the mid-eighteenth century}

Many early written accounts are listed in the comprehensive works by Mougin (1912) and Le Roy Ladurie (1967). Glaciers in the valley of Chamonix are advancing and approaching cornfields in 1575-1576 (Le Roy Ladurie 1967: 108). In 1580, the menace to the people is proved by the detailed (and notably first) description of the glaciers of Chamonix by Bernard Combet, Archdeacon of Tarentaise (historic province of Savoy). Complaints by inhabitants, which could not any more meet their fiscal duty, made Combet get an idea of his own of the situation in the valley of Chamonix. According to that report, the Glacier des Bossons nearly reached down to the valley floor (see Nussbaumer et al. 2007, for more details about this informative document). 


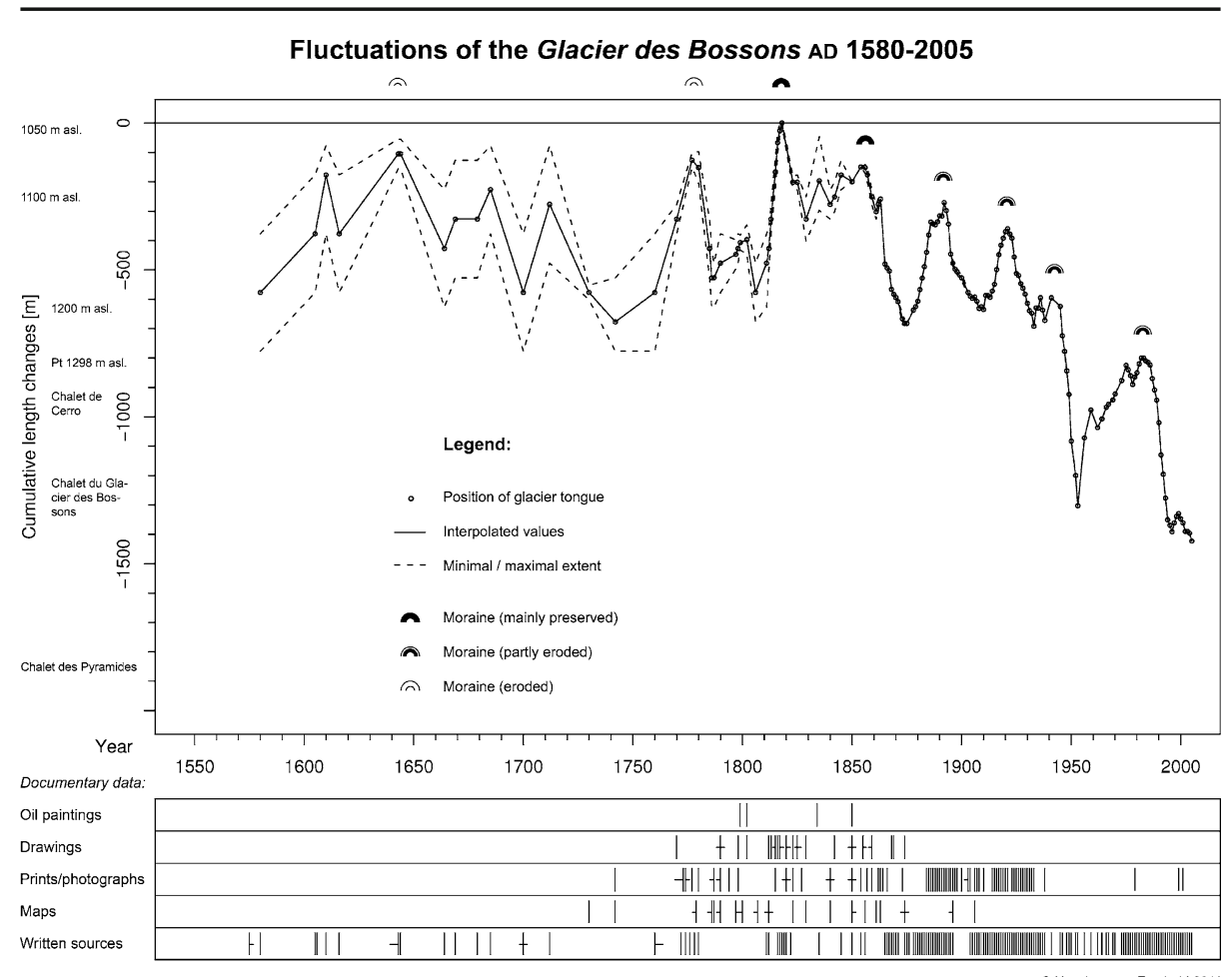

Fig. 3 Cumulative length changes of the Glacier des Bossons from 1580-2005, relative to 1818 (=0; maximum of the LIA). Dots were derived from reliable historical sources shown in the compilation below the $\mathrm{x}$-axis, where small horizontal lines indicate uncertainties concerning the date of the document. Landmarks are indicated beside the y-axis (cf. Fig. 10). Data for the 19212005 period from the Laboratoire de Glaciologie et Géophysique de l'Environnement (LGGE) in Grenoble, provided by the World Glacier Monitoring Service (www.wgms.ch)

In 1605-1610, a serious glacier advance is documented, although the devastation of farmland near to the Glacier des Bossons seems to be less than at the glaciers upvalley (i.e., Mer de Glace, Glacier d'Argentière, and Glacier du Tour; Kinzl 1932: 287). This is also confirmed by Saint François de Sales, bishop of Geneva from 1602-1622, during his missions in the diocese, and by a report of Nicolas Grandjean (Mougin 1912: 45; Le Roy Ladurie 1967: 126). The advance culminated in 1643, when farmland above les Montquarts was devastated by the advancing glacier ice (Mougin 1912: 48; Kinzl 1932: 287). However, there is no indication and no moraine proving a larger glacier extent compared to the situation in the nineteenth century (the LIA maximum occurred in 1818; cf. Section 4.1.3). In 1644, a benediction of the glacier was pronounced by Charles-Auguste de Sales (appointed bishop of Geneva-Annecy in 1645). Sporadic written accounts document rather large glacier extents until the end of the seventeenth century (maximum in 1685), leading to a small glacier extent at the turn to the next century, and to a subsequent re-advance around 1712 (Mougin 1912: 48; Le Roy Ladurie 1967: 149, 152).

A precise argument is possible for 1730, when the retreating Glacier des Bossons is depicted in the first pictorial and cartographical document, the "Cadastre Sarde". 
This first topographical survey of Savoy, initiated under the monarch of Sardinia, Victor-Amédée II, and accomplished from 1728-1731 (Baud et al. 2008), is a unique source for different applications in geographic, economic and social contexts (Guichonnet 1955). The area of Chamonix and the Glacier des Bossons were surveyed in 1730. The comparison of the plan with modern maps yielded an astonishing accuracy for certain areas, including the surroundings of the Glacier des Bossons (Fig. 4). According to that cadastral plan, the glacier front was about $570 \mathrm{~m}$ behind the maximum LIA extent in 1818, which is also confirmed by Mougin $(1912: 46,48)$ and Le Roy Ladurie (1967: 170).

Another cartographical document is the 1742 sketch by Pierre Martel, an engineer from Geneva. After the visit of the valley of Chamonix and particularly the Mer de Glace by the two Englishmen William Windham and Dr Richard Pococke in 1741 (Cunningham 1990: 19), Martel drew the first specific though very simple glacier map of the Mont Blanc area. This map was complemented by a side view of the valley of Chamonix, and it named peaks and glaciers as a great novelty (Martel 1744). The map shows glaciers as cascades of ice coming from a central reservoir where snow and ice is accumulated, which was apparently quite a common perception of glaciers in the eighteenth century (Aliprandi and Aliprandi 2007: 125).

Fig. 4 "Cadastre Sarde" including the Glacier des Bossons, representing the valley of Chamonix in 1730. The outermost LIA moraines from 1818 and the glacier extent in 2001 are added (Archives départementales de la Haute-Savoie, Annecy; photograph kindly provided by P. Deline, Université de Savoie)

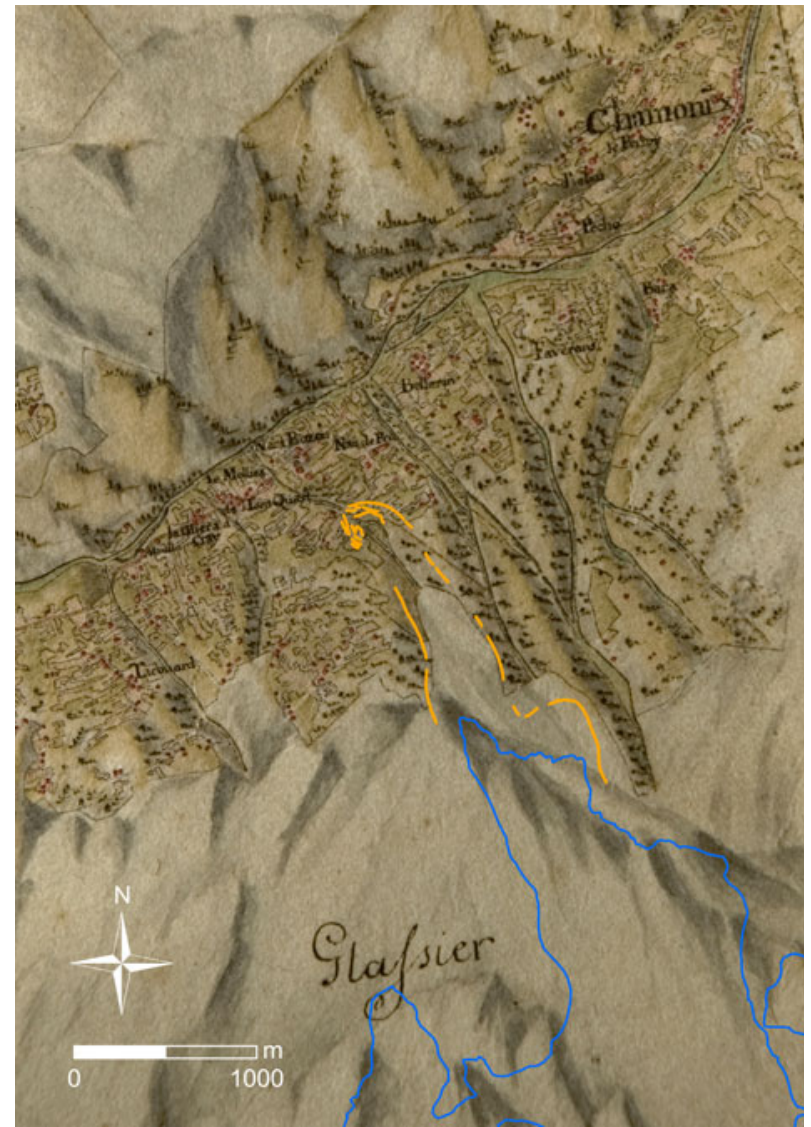




\subsubsection{Beginning of alpinism and glacier advance and retreat in the late eighteenth century}

From 1760 onwards, the Glacier des Bossons was advancing, as documented by a report of the great natural scientist from Geneva, Horace-Bénédict de Saussure (Le Roy Ladurie 1967: 184), and by the watercolour by William Pars, made 21-24 July 1770. Bordier (1773: 197, 219) describes the Glacier des Bossons fast advancing, with an impressive and steep glacier front. Other evidence for the 1770s glacier advance is given by Bourrit (1773), by the contour etching by François Jalabert from 1777, and by the works of de Saussure with a description for 1778 (de Saussure 1779: 387; Wetter 1987: 193). In 1780, William Coxe documents the glacier retreating again (Mougin 1912: 48), and a coloured contour etching by Carl Ludwig Hackert from 1780 still shows the glacier close to the LIA maximum.

In the late $1780 \mathrm{~s}$, historical material is more abundant, which leads to a more accurate delineation of the glacier's fluctuations. Hans Conrad Escher von der Linth (5 August 1785), Jean-François Albanis Beaumont (1787), Charles-François Exchaquet (1787), Christian von Mechel (1787/1790), Jean-Philippe Linck (1790), Marc Théodore Bourrit (1798) and Jean-Antoine Linck (1798/1799) give us a detailed picture of the valley of Chamonix. It was also the time of the first ascent to the summit of Mont Blanc by the two Chamoniards Jacques Balmat and Dr Michel Gabriel Paccard on 8 August 1786, and the third ascent by de Saussure and Balmat on 3 August 1787. The traditional route to the summit of Mont Blanc follows the Glacier des Bossons (Gîte à Balmat-Jonction-Grands Mulets-Grand Plateau), which explains the high number of historical accounts and (pictorial) documents that appear from now on and reveal the glacier in all its facets.

Two accurate oil paintings, by Jean-Antoine Linck ("L'extrémité du glacier des Bossons", made in 1799; Vellozzi 1990: 59), and by William Delamotte in 1802, depict the Glacier des Bossons slightly advanced at the turn to the nineteenth century. Moreover, cartographical documents from the same time period confirm the glacier front position determined: "Carte physique et minéralogique du Mont Blanc et des montagnes et vallées qui l'avoisinent" (1797-1799) by Jean-Baptiste Raymond, “Atlas Suisse par Weiss et Meyer" (1800), and the Mont Blanc relief (around 1800) by Ferdinand Rudolf Hassler (Rickenbacher 2007).

Summing up, the Glacier des Bossons was advancing by $450 \mathrm{~m}$ from 1760 until 1777 , when its tongue reached a position roughly $120 \mathrm{~m}$ behind the 1818 maximum (note that historical sources are few for 1740-1760). The glacier was in an advanced position until 1780, and was retreating thereafter by $375 \mathrm{~m}$ until 1786 . At the turn to the nineteenth century, the glacier showed a minor advance.

\subsubsection{Well-documented glacier advances in the nineteenth century}

From 1811-1818, the Glacier des Bossons was highly advancing, as documented by several independent sources (Birmann 1826; Viollet-le Duc 1876; Forel 1889; Ritter 2008). The very detailed description of the Glacier des Bossons by Samuel Birmann in his sketchbook on one of his journeys to the valley of Chamonix reveals that the glacier was advancing most in 1817 ( 3 or $4 \mathrm{ft}$ in $24 \mathrm{~h}$ ), covering arable land, and retreating again in 1819 (Birmann 1826; see Appendix for full text).

There is a general consensus on the timing of the maximum of this advance (1818; Mougin 1912: 48; Wetter 1987: 197). The advance is furthermore documented by 
several drawings by Jean-Antoine Linck (1813, 1816, 1817/1818) and Hans Conrad Escher von der Linth (8 August 1816), and by a print by Mathias Gabriel Lory (1815; Priuli and Garin 1985: 78). The watercolour "Vue de Glacier de Bossons de l'Aiguille du Midi et du Tacul" by Linck (Dobiaschofsky Auktionen 2009; Fig. 5) shows the glacier at its maximum position or shortly before, protruding into the forest at its upper right lobe and forming an impressive glacier tongue. At the same time, Linck documents on another drawing the devastation by the glacier at the right-hand side moraine from 1818 (Fig. 6). At that point, a cross was erected in 1818 in order to stop the glacier (Mougin 1912: 49).

The glacier advance from 1811-1818 adds up to almost $480 \mathrm{~m}$. The following retreat was, according to the local Venance Payot, fast at the beginning (Mougin 1912: 48). Five years after the nineteenth century maximum, several drawings from different points of view by Samuel Birmann give a precise delineation of the Glacier des Bossons in 1823. The rapid glacier retreat is clearly visible, as can be seen from the barren land left by the glacier (Fig. 7).

A slight glacier advance is documented for 1835 (Viollet-le Duc 1876: 107/108), however, reliable pictorial and cartographical documents are only available for 1829 (drawing by Edward Backhouse and map by François-Jules Pictet) and 1842 (drawings by John Ruskin). The glacier was increasing in 1845 according to the

Fig. 5 Glacier des Bossons around its nineteenth century maximum, portrayed by Jean-Antoine Linck ("Vue de Glacier de Bossons de l'Aiguille du Midi et du Tacul"; signed bottom right; watercolour; $44.5 \times 33.7 \mathrm{~cm}$; private collection; photograph by S. U. Nussbaumer, with kind permission of Dobiaschofsky Auktionen AG, Bern)

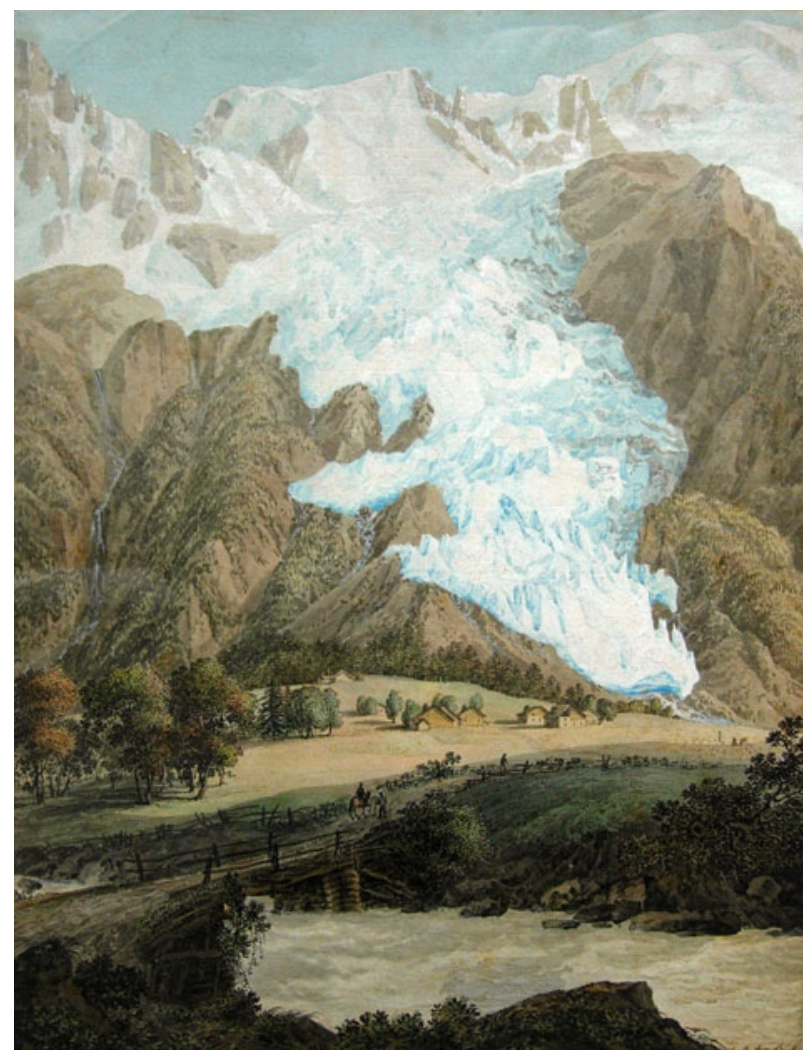




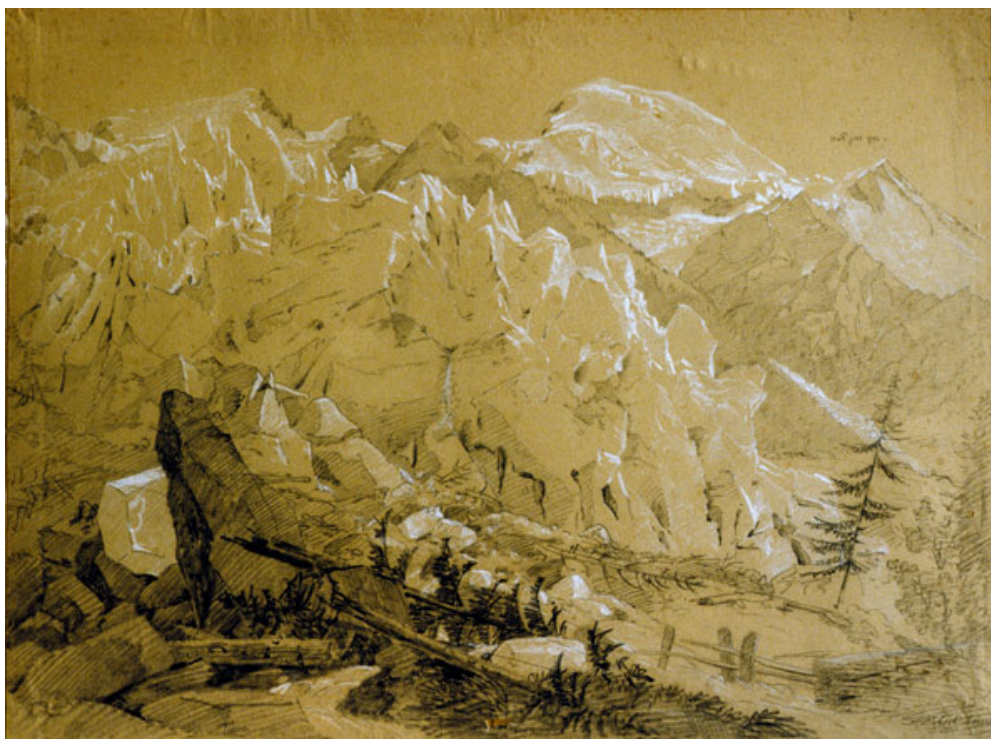

Fig. 6 Front of the Glacier des Bossons around its nineteenth century maximum by Jean-Antoine Linck ("Le Glacier des Bossons et le Montblanc"; signed bottom right; black and white chalk, on beige paper; $42.2 \times 57.1 \mathrm{~cm}$; Conservatoire d'art et d'histoire $(\mathrm{CAH})$, Annecy, Collection Paul Payot, LNSA 09; photograph by H. J. Zumbühl)

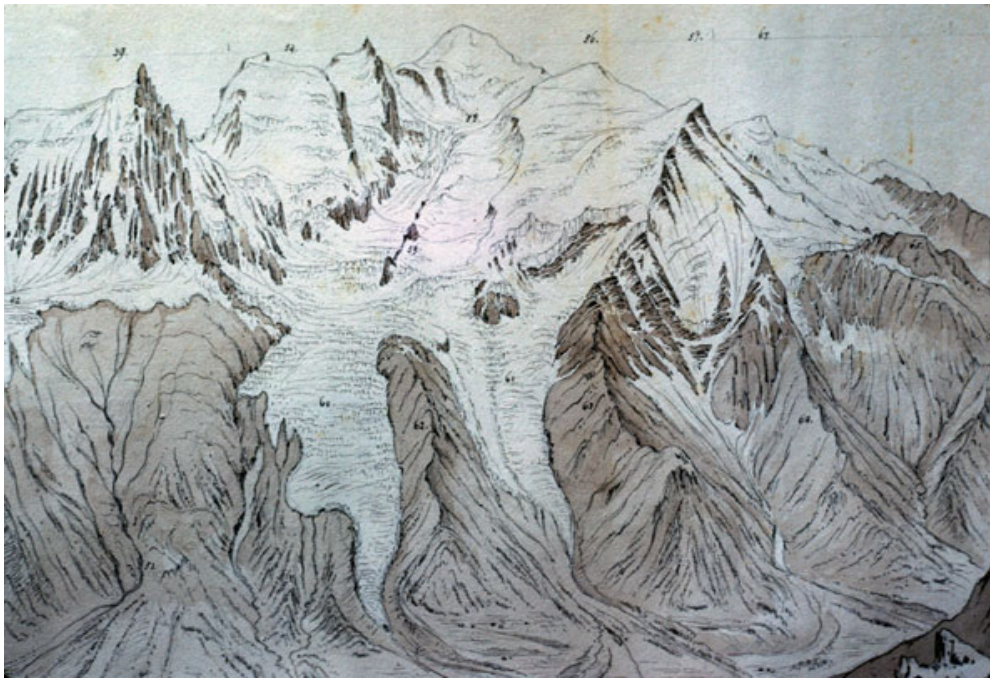

Fig. 7 Cut-out from the panorama from the summit of le Brévent showing the valley of Chamonix with the Glacier des Bossons and Glacier de Taconnaz (to the right), dominated by the Mont Blanc, drawn by Samuel Birmann in 1823. "J'ai choisi le panorama du Bréven entre les différents que je possède, parce qu'il donne le mieux les détails de la chaîne du Mont-Blanc, tel qu'on le voit ordinairement, et qu'il présente, si je puis m'exprimer ainsi, la face de ce colosse imposant"; Birmann (1826) ("N:454. Samuel Birmann. Ad. nat. f. au sommet du Brévent 1823."; pencil and watercolour; $46.7 \times 225.5 \mathrm{~cm}$; Kunstmuseum Basel, Kupferstichkabinett, Inv. Bi.417; photograph by H. J. Zumbühl, with kind permisson of Kunstmuseum Basel) 
mountain guide Alphonse Balmat (Forel 1889) and measured in 1850 and 1854 by Venance Payot (Mougin 1912: 48). This second maximum in the nineteenth century was reached in 1854 , leaving moraine ridges that are $150 \mathrm{~m}$ behind the 1818 moraines. Important pictorial documents for the $1850 \mathrm{~s}$ are several drawings by Anton Winterlin (from around 1850) and Alfred Guesdon, the map by James David Forbes at the scale of 1:50,000 (published in Forbes 1855), and finally the photographs by Frédéric Martens (from 1859) and by the French Bisson brothers (published between 1857-1863; Chlumsky et al. 1999).

\subsubsection{Glacier retreat since the end of the LIA}

Continuous measurements of the glacier front were initiated in 1863/1865 by Venance Payot. They document a retreat of almost $425 \mathrm{~m}$ from 1863-1874 (Mougin

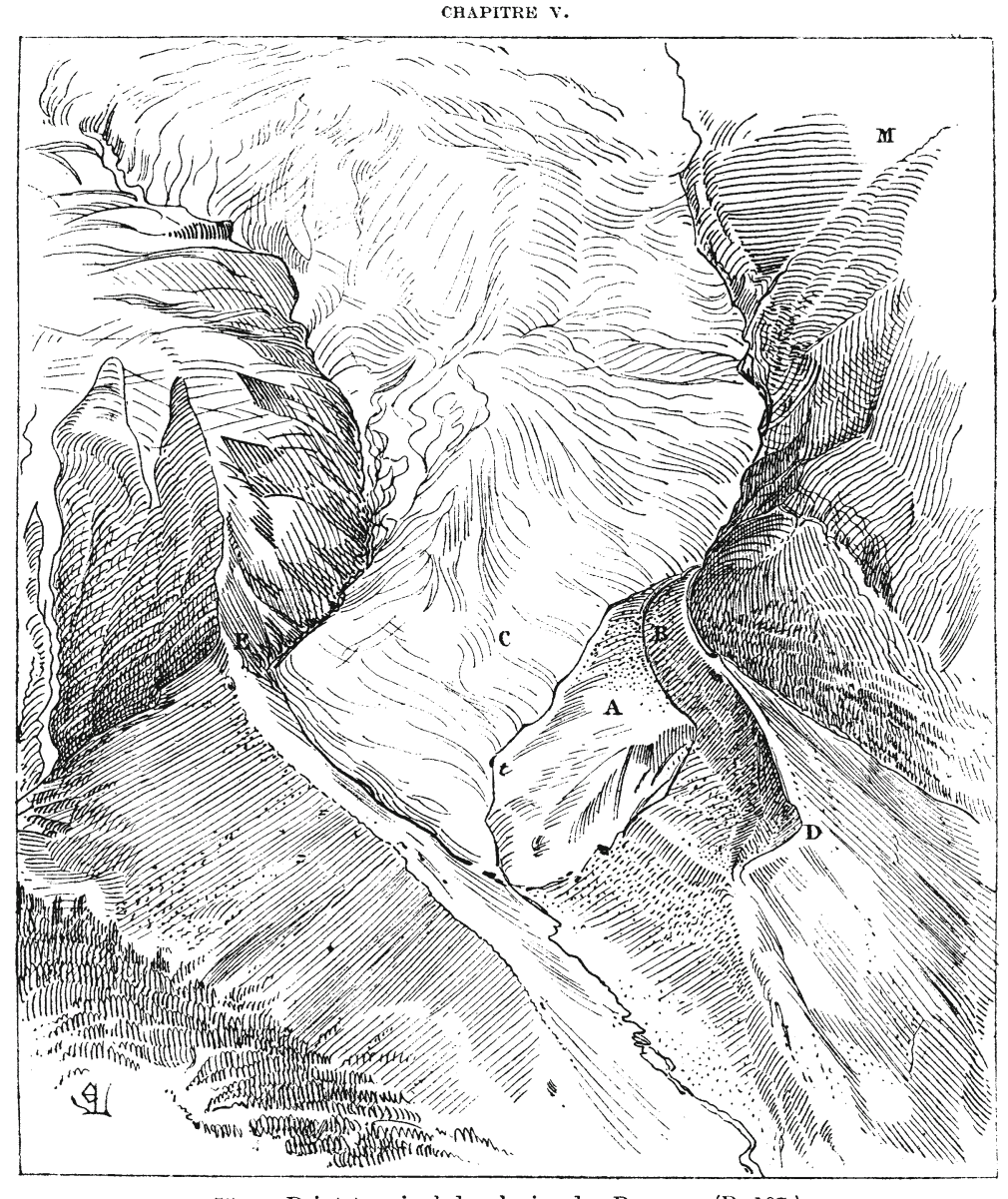

55. - Point terminal du glacier des Bossons. (P. 107.)

Fig. 8 Front of the Glacier des Bossons in July 1873, drawn by Eugène Viollet-le Duc (Viollet-le Duc 1876: 107; reproduction by S. U. Nussbaumer) 
1912: 48). For that time period, the works by Eugène Viollet-le Duc are a very precious source. Viollet-le Duc, primarily a French architect and theoretician of architecture, was passionate about glaciers later in his life (Frey 1988). His famous map of the Mont Blanc massif and his drawings and sketches were produced between 1868 and 1875, e.g. the sketch showing a frontal view of the tongue of the Glacier des Bossons in July 1873 (Fig. 8; Viollet-le Duc 1876).

From 1875-1892, another advance by $410 \mathrm{~m}$ left a corresponding moraine ridge. This advance as well as the consecutive glacier history until 1920 is reported more or less continuously by Venance Payot and later on by Mougin (1912, 1925). Visually, the glacier fluctuations are captured on classical photographs by Joseph and Georges Tairraz from Chamonix. The turn to the twentieth century is also characterized by a technology newly developed, the photochrom prints, which are the first photographic colour images available (Fig. 9; Arqué et al. 2009). Very accurate and well-known is also the "Carte du massif du Mont Blanc" by the French Vallot (map at the scale of 1:20,000; tongue of the Glacier des Bossons represented as of 23 August 1906; Vallot et al. 1925; Vivian 1986).

Glacier front changes from 1921 onwards were obtained from the World Glacier Monitoring Service (www.wgms.ch). These data are held and regularly updated by the Laboratoire de Glaciologie et Géophysique de l'Environnement (LGGE) in Grenoble, France. Minor glacier advances peaked in 1921, 1941, and 1982/1983, respectively. Note the remarkable retreat (by more than $700 \mathrm{~m}$ ) starting in the $1940 \mathrm{~s}$, and also the following re-advance by about $500 \mathrm{~m}$ until the 1980s (Fig. 9).

\subsection{Glacier foreland and moraines}

Several moraines were formed during the LIA by the Glacier des Bossons. Moraines built earlier during the Holocene, and even the first LIA moraines (from the 1640s
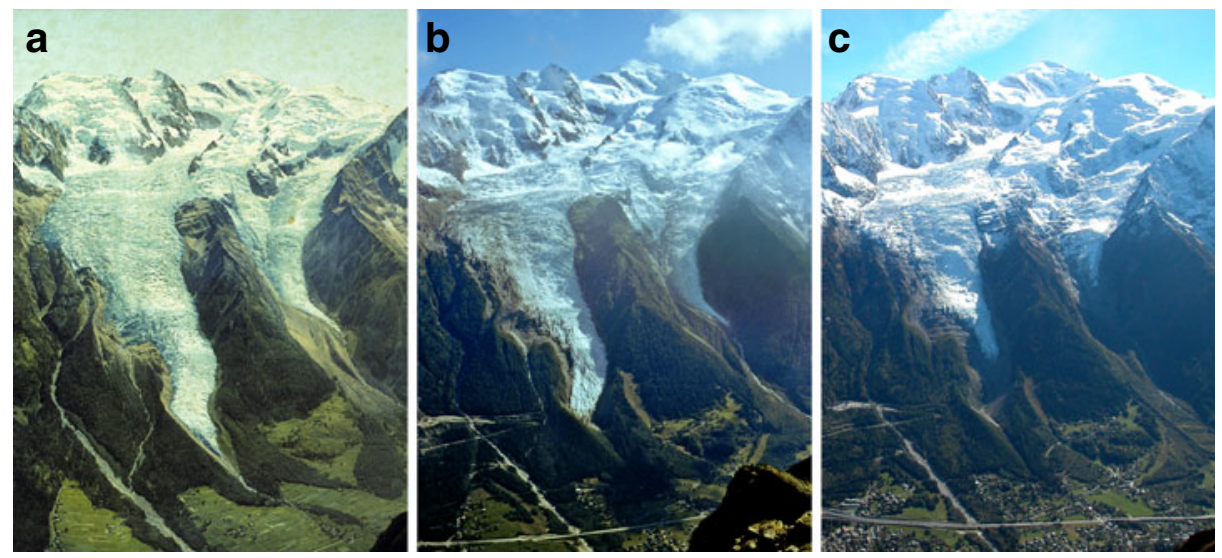

Fig. 9 Glacier des Bossons seen from le Brévent a before 1906 ("Le massif du Montblanc vu du Brévent", cut-out; photochrom print; $27.0 \times 80.0$ cm; CAH, Annecy, Collection Paul Payot; photograph by H. J. Zumbühl), b on 22.09.1983 (relative glacier maximum; photograph by H. J. Zumbühl), c on 08.10.2005 (photograph by S. U. Nussbaumer) 
and 1770s), are probably overwhelmed by the latest LIA glacier advances, as shown by fossil woods found by Wetter (1987) at three levels in the inner flank of the large right-hand moraine. Fossil wood found in the moraines of the Glacier de Taconnaz proves glacier advances around 1630 and 1680 according to radiocarbon dating (Corbel and Le Roy Ladurie 1963).

According to the historical evidence, the outermost (frontal) moraine is from 1818 (Fig. 10). A trunk of fossil wood overwhelmed under a large boulder of the outermost moraine of the right lobe of the glacier was dated by Wetter (1987: 234) and confirms the moraine accumulation of around 1820.

The moraine from 1854 is close to the maximum extent and well-preserved. According to the map of the glacier foreland in 1911, made by Mougin (1912), also the moraine from 1892 was well-preserved at that time. Today, it is only conserved at the frontal part, as strong erosion still happens at both very steep lateral walls (LIA maximum moraines bordering the glacier foreland). Throughout the twentieth century, minor glacier advances led to the formation of three younger moraines, which are, though, largely eroded (Fig. 10).

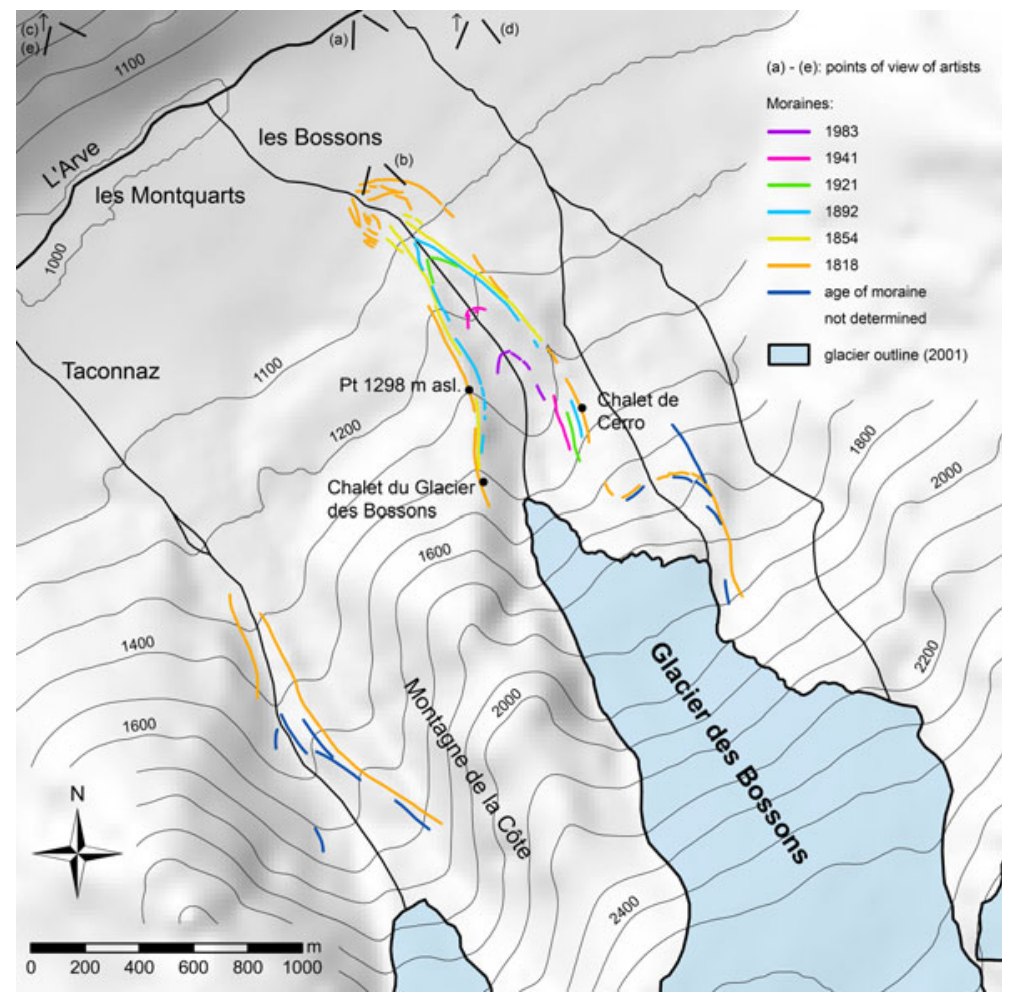

Fig. 10 Glacier foreland and LIA moraines (modified after Mougin 1912, and Wetter 1987) of the Glacier des Bossons. Points of view of artists are given accordingly: (a) Jean-Antoine Linck (Fig. 5), (b) Jean-Antoine Linck (Fig. 6), (c) Samuel Birmann (from le Brévent; Fig. 7), (d) Eugène Viollet-le Duc (from the other valley side; Fig. 8), (e) Photochrom Zürich (from le Brévent; Fig. 9) 


\section{Discussion}

\subsection{Glacier length records for the western and central Alps}

A comparison of the new length curve for the Glacier des Bossons with length fluctuations determined by Mougin (1912) shows a general agreement. However, a refinement of the length curve was possible thanks to historical sources newly evaluated, especially from the mid-eighteenth century up to the 1860s (Fig. 11).

Figure 12 compares the Glacier des Bossons with the nearby Mer de Glace (cf. Nussbaumer et al. 2007) and two other glaciers richly documented historically. Similar to the Mont Blanc glaciers, the extraordinary low position of the terminus and its easy accessibility make the Unterer Grindelwaldgletscher one of the bestdocumented glaciers in the Swiss Alps, and probably in the world (Zumbühl 1980). The curve of cumulative length fluctuations, derived solely from documentary evidence, covers the period 1535-2004 and includes the two well-known glacier maxima about 1600 and 1855/1856 (cf. Zumbühl 1980; Zumbühl et al. 1983; Holzhauser and Zumbühl 1996; Steiner et al. 2008b). The reconstruction of the Oberer Grindelwaldgletscher goes back to AD 1590 and shows LIA glacier maxima around 1600, 1720, 1777/1778, 1820-1822, and 1854/1855 (Zumbühl 1980).

Both the Glacier des Bossons and the Oberer Grindelwaldgletscher react faster than their neighbouring glaciers. This can be observed throughout the whole reconstruction time. The climate impact on two adjacent glaciers is reflected differently dependent on the size and slope of the glaciers (Kuhn et al. 1985). Both Mer de Glace and Unterer Grindelwaldgletscher are larger and flatter than the Glacier des Bossons or the Oberer Grindelwaldgletscher.

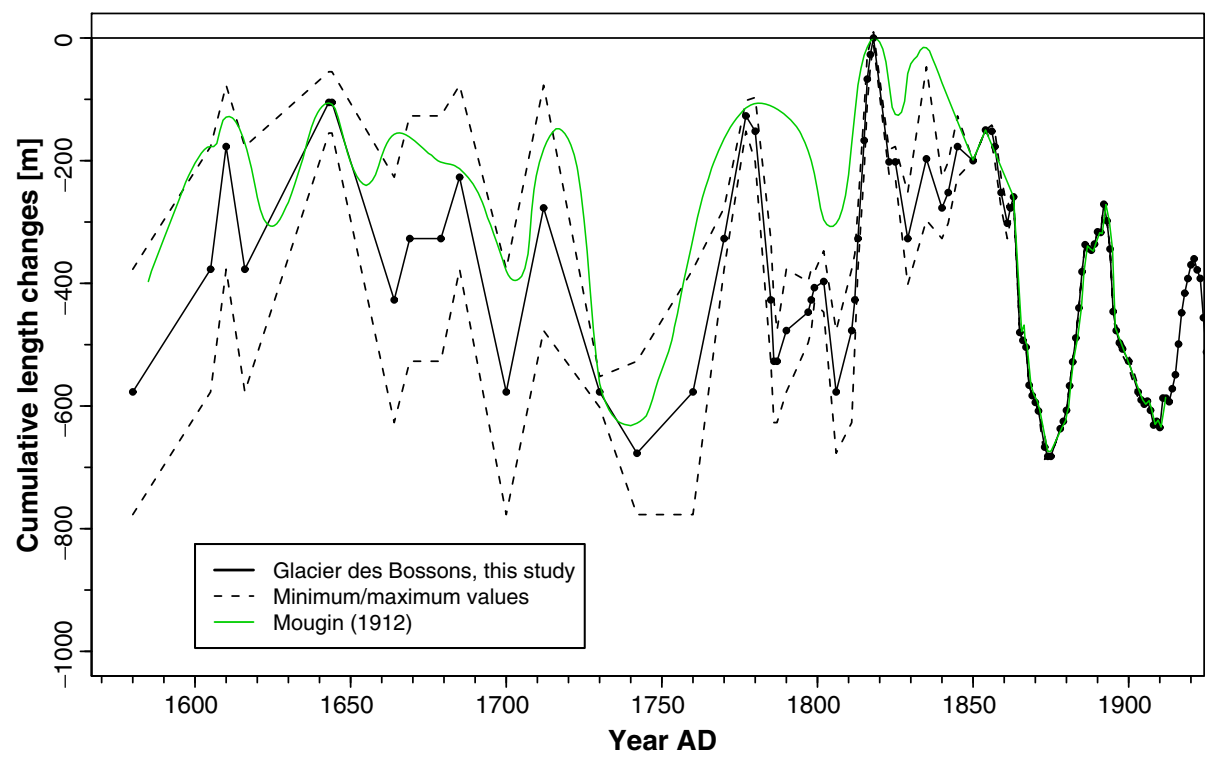

Fig. 11 Length changes of the Glacier des Bossons compared with results from Mougin (1912) 


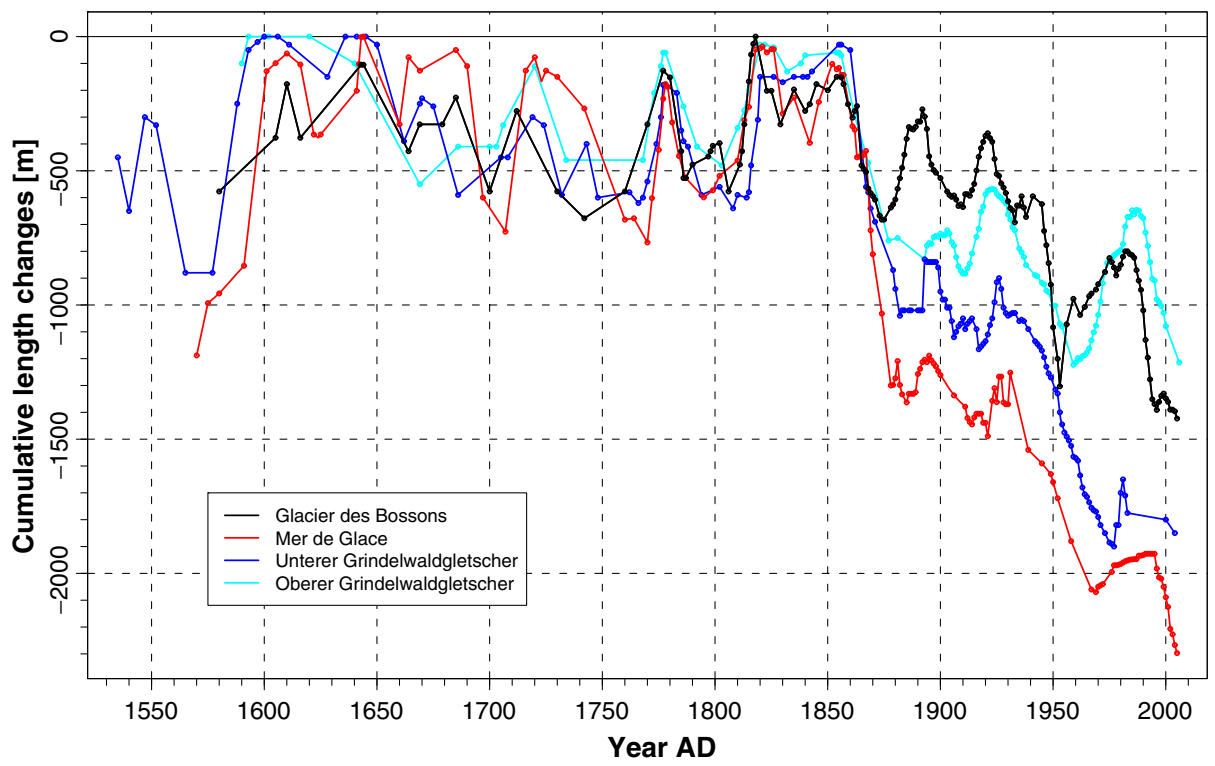

Fig. 12 Length changes of four well-documented Alpine glaciers, based on historical sources (Mer de Glace: Nussbaumer et al. 2007; Unterer Grindelwaldgletscher: Zumbühl 1980; Zumbühl et al. 1983; Zumbühl et al. 2008; Oberer Grindelwaldgletscher: Zumbühl 1980; Gletscherberichte 1881-2009)

All glaciers (except for the Glacier des Bossons) had their LIA maximum in the first half of the seventeenth century. A distinct correspondence results for the advances in the late 1770 s and around 1820. Only the Unterer Grindelwaldgletscher shows its nineteenth century maximum around 1850 . The retreat of all glaciers from about $1850-1875$ is unprecedented in historical time. After the shrinkage of the glaciers during the twentieth century, also the perception of them has changed, in the Mont Blanc area as well as in the valley of Grindelwald: from a threat to the inhabitants when reaching down to the valleys, to possible disappearance from the areas at lower elevations.

\subsection{Climatic interpretation}

Changes in glacier length are, in contrast to glacier mass balance, to be treated as a more indirect, filtered, enhanced and delayed climate signal ("reaction time" of the glacier tongue to a climate perturbation, based on the kinematic wave velocity; Nye 1965; Paterson 1994; Hoelzle et al. 2003). The "response time" on the other hand is the time required for a glacier to adjust from one "steady-state" to another, following a change in the mass balance (Jóhannesson et al. 1989; cf. Table 1). Usually this time is two to three times longer than the "reaction time" mentioned before (Steiner et al. 2008a). However, it must be noted that the reaction to atmospheric conditions at the glacier snout can also be more immediate in some situations, e.g. after runs of cool summers (Matthews and Briffa 2005).

Figure 13 compares changes in the length of Glacier des Bossons with 20-year low-pass filtered summer temperature and winter precipitation data (multi-proxy 


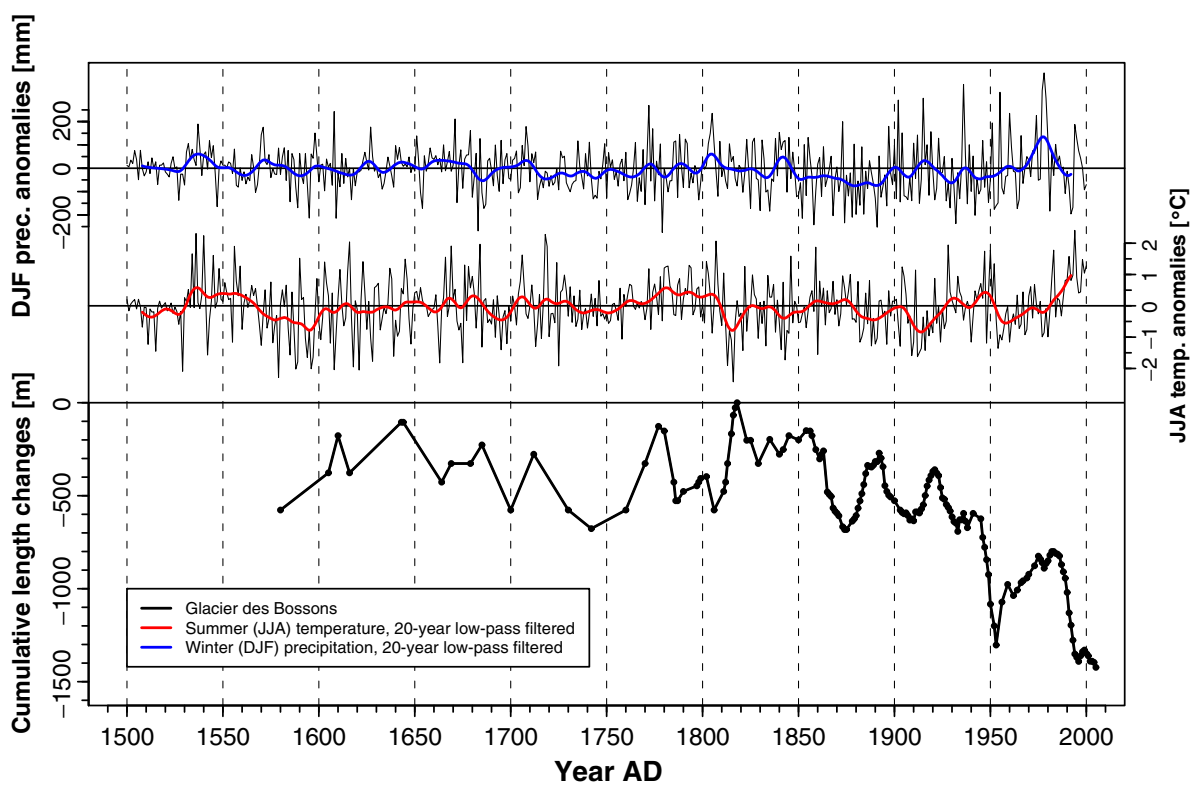

Fig. 13 Cumulative length changes of the Glacier des Bossons and mean summer $(J J A)$ temperature and winter $(D J F)$ precipitation anomalies (reference period 1901-2000) from 1500 to 2000 (multiproxy reconstruction by Casty et al. 2005; grid point $45.75^{\circ} \mathrm{N} / 6.75^{\circ} \mathrm{E}$ ). Climate data were smoothed by a 20-year Gaussian low-pass filter (bold lines)

climate reconstructions for the Alpine area by Casty et al. 2005). Alpine glacier mass balances are largely controlled by summer temperature and winter precipitation (e.g., Oerlemans and Reichert 2000). A simple comparison of the local minima and maxima in summer temperature with glacier maxima and minima yields a frontal time lag of 2-10 years for the Glacier des Bossons. The maximum cross-correlation between these two records is reached when setting a 1-2-year lead of the summer temperature signal relative to the Glacier des Bossons.

A similar comparison between summer temperature and the frontal changes of the Mer de Glace yields a delayed reaction the glacier tongue of 11-25 years. However, a cross-correlation analysis between those records is not significant. This is in agreement with Reynaud (1993) who found, based on the analysis of the glacier records since 1870 , that the Mer de Glace had its minimum frontal position 11-15 years after the shorter and steeper Glacier des Bossons. The correlation between the length records of Mer de Glace and Unterer Grindelwaldgletscher is $\mathrm{r}=0.81(\mathrm{p}<0.05)$ when setting a 1-year lead of the Mer de Glace relative to the Unterer Grindelwaldgletscher (Nussbaumer et al. 2011).

However, there is complex interplay between different seasonal climate parameters influencing glacier dynamics. Using a glacier-climate model based on neural networks, Steiner et al. (2008a) showed that different combinations of seasonal temperature and precipitation have led to glacier variations, and that the 1810 1820 advance of the Unterer Grindelwaldgletscher was mainly due to low summer temperatures. According to Vincent et al. (2005), who studied Alpine glacier variations for the period $1760-1830$ as a whole, the advance of glaciers was also 
due to increased winter precipitation during that time, and glacier recession after 1830 clearly resulted from a decrease in winter precipitation and not a temperature increase. On the other hand, the strong glacier melt in the 1940s can be attributed to enhanced solar radiation (Huss et al. 2009; cf. also Nussbaumer et al. 2011, for a discussion of historical glacier records and solar activity).

Other historical evidence indicates that the glacier advances in the late sixteenth and early seventeenth century coincided with recurrent subsistence crises and multiple floods in the Alps (Pfister 2007). The extensive advance of the Glacier des Bossons at that time devastated arable land, and complaints by the residents led to the first descriptions of the glacier. Generally, the north side of the Alps was afflicted by frequent cold and rainy summers, which were the result of a series of volcanic explosions in the tropics (Luterbacher et al. 2004; Pfister 2007).

A similar pattern can be observed for the glacier advance in the 1820 s. From 1812 to 1817, Viollet-le Duc (1876: 107/199) reports that at Chamonix, the winters were long and cold, and the summers very humid with a lot of rain. The winter 1829/1830 was particularly rigorous. Volcanic eruptions in 1809 (unknown location) and 1815 (Tambora) were responsible for low temperatures in the northern hemisphere from 1810-1819, which was probably the coldest decade during the past 500 years or longer according to Cole-Dai et al. (2009), including the "year without a summer" in 1816 (Pfister 1999). Superimposed to low solar activity during the Dalton Minimum between 1810 and 1820 (Steinhilber et al. 2009), there is a volcanic forcing leading to cold and humid summers in Europe (Fischer et al. 2007).

In the Alps, positive mass balances or glacier length changes correlate well with low solar and volcanic forcing (Wanner et al. 2008). A negative regime of the North Atlantic Oscillation (NAO) might be a key feature of cold Little Ice Age Type Events (LIATEs; Wanner et al. 2000), causing glacier advances in Europe. Recently, Huss et al. (2010) showed a significant anti-correlation of Alpine glacier mass balances to variations in the Atlantic Multidecadal Oscillation (AMO) and the related summer temperature signal. However, glacier mass balances are also dependent on the hygric regime (precipitation and evaporation). Winter precipitation in the Alps is controlled by the continental circulation dynamics (Wanner et al. 2003). In winter, the NAO is the dominant mode explaining most of the variability of the precipitation and temperature fields over this area, i.e. a more zonal circulation with warm and wet westerly winds or a blocking state with very cold and dry easterly winds. Most favourable for positive mass balances in the Alps, though, is a rather meridional circulation with a northerly to north-westerly upper air flow, bringing cool weather with high precipitation. For example, the major glacier advances in the Alps from 1820 to 1850 coincide with predominant north-westerly and northerly air flow (Jacobeit et al. 2003; Küttel et al. 2011).

\section{Conclusions}

Historical descriptions of glaciers are accurate, but limited in space and time. Historical material is only available in adequate quantity for those glaciers which drew the attention of the people through their reputation and scenic attraction, reflecting also the perception of glaciers at that time. This is the case for the Glacier des Bossons and Mer de Glace (Mont Blanc area) as well as for the Unterer and Oberer 
Grindelwaldgletscher (Bernese Alps). Using these data, a resolution of decades or, in some cases, even individual years of ice margin positions is achieved.

The revised glacier length record for the Glacier des Bossons spans the time period from AD 1580-2005 and shows high variability (fast reacting glacier). The Little Ice Age (LIA) maximum extent was reached in 1818. Other glacier maxima occurred around 1610/1643, 1685, 1712, 1777, 1854, 1892, 1921, 1941, and 1983. Pictorial documents newly compiled, mainly from the 1770 s until the end of the nineteenth century, give valuable insight into the glacier's fluctuations.

The reconstruction of the Mer de Glace extends back to AD 1570, with a maximum glacier extent around 1644 (largest extent during the LIA), and a slightly smaller maximum in 1821 and a second advance in 1852. The cumulative length fluctuations of the Unterer Grindelwaldgletscher, derived from documentary evidence, cover the period 1535-2004 including the two well-known glacier maxima about 1600 (LIA maximum) and 1855/1856. A comparison of the length curves of the glaciers studied in the Mont Blanc area with the two Grindelwald glaciers shows an astonishing simultaneity between the glaciers. In both mountain areas, valley glaciers were threatening inhabitants from the sixteenth to the nineteenth century, and becoming since the mid-eighteenth century a desired object of study for scientists, artists and travellers.

Acknowledgements The authors wish to thank H. Holzhauser for field assistance and dating of tree ring samples from the foreland of the Glacier des Bossons, R. Kunz for field expertise, P. Hänggi, H. Machguth and M. Trachsel for very valuable comments on the manuscript, and P. Deline for providing the 1730 cadastral map. T. Bader and B. Luckman are very much acknowledged for proofreading. The constructive comments by the reviewers greatly improved the paper. A great deal of institutions and archives provided access to the iconographic material. The following institutions kindly allowed publishing important pictorial documents: Conservatoire d'art et d'histoire, Annecy; Dobiaschofsky Auktionen AG, Bern (J. O. T. Scharf); Kunstmuseum Basel (Kupferstichkabinett). S. U. Nussbaumer has been funded by the Swiss National Science Foundation, grant 200021-116354.

\section{Appendix}

\section{Description of the Glacier des Bossons by Samuel Birmann}

Aucun glacier de la vallée de Chamonix ne présente des tours et des pyramides de glace aussi grandes et aussi bien coupées que celui qu'on a sous les yeux. Du temps que les glaciers croissoient considérablement, ces masses étoient prodigieuses, encore à présent elles surpassent en hauteur les clochers. Leurs formes variables ont un caractère fantastique, qui doit frapper à la seule inspection de ce dessin, fidèlement tracé d'après nature.

Le glacier des Bossons (Buissons) descend presque en ligne droite des plateaux les plus élevés du Mont-Blanc, et la pureté de ses glaces, se conservant jusqu'au bas, forme un contraste frappant avec les teintes foncées des bois de sapins et de melèzes qui garnissent ses bords. La pente de ce glacier étant très rapide, il est le premier de la vallée à croître et à se retirer. J'ai ouï-dire que, dans l'année 1817, où il augmenta le plus, les glaces s'avançoient de trois ou quatre pieds dans les vingt-quatre heures, et qu'elles couvrirent pour plus de trois mille francs de bonnes terres cultivées; la moraine s'étendit au-delà de 
tous les indices qu'on avoit conservés des descentes plus anciennes. Quelque temps après, le glacier s'arrêta, se dégonfla peu-à-peu, et vers l'an 1819 on le vit commencer à reculer; et à cette heure un grand espace de terrain couvert de gravier et de grosses pierres sépare les glaces des terres labourables.

Les habitants de la vallée de Chamonix prétendent avoir observé que dès l'année 1811 les glaciers ont commencé à croître, et qu'ils ont continué à le faire jusqu'en 1817. Dans cette contrée comme dans plusieurs autres du Tyrol et de la Suisse, on trouve accréditée l'opinion que les glaciers augmentent pendant sept ans, et décroissent pendant les sept années suivantes. Mais la vîtesse de leur accroissement dépend de plusieurs circonstances: la quantité de neige tombée en est une; et il faut y joindre l'inclinaison du sol que parcourent les glaces, et la distance d'où elles viennent; c'est ainsi que l'expérience nous apprend que le glacier des Bossons se retire, tandis que celui des Bois augmente encore; et en effet ce dernier avança jusqu'en 1821.

On passe le glacier des Bossons en trois endroits; en haut, en escaladant le Mont-Blanc pour arriver aux grands Malets; en bas, on s'amuse à faire le trajet pour s'en retourner par une autre route au Prieuré.

(Birmann 1826: accompanying text to aquatint sheet No. 15)

Compilation of historical data

Table 2 Summation of historical documents that have been used to reconstruct front variations of the Glacier des Bossons within this study

\begin{tabular}{|c|c|c|c|c|}
\hline Date & $\begin{array}{l}\text { Type of } \\
\text { document }\end{array}$ & $\begin{array}{l}\text { Observer/ } \\
\text { author }\end{array}$ & Owner & Literature \\
\hline $1575 / 1576$ & Written source & Local & $\begin{array}{l}\text { Archives départementales } \\
\text { de la Haute-Savoie, } \\
\text { Annecy }\end{array}$ & $\begin{array}{l}\text { Le Roy Ladurie (1967), } \\
\text { Wetter (1987) }\end{array}$ \\
\hline 1580 & Written source & B. Combet & $\begin{array}{l}\text { Archives départementales } \\
\text { de la Haute-Savoie, } \\
\text { Annecy }\end{array}$ & $\begin{array}{l}\text { Mougin (1912), } \\
\text { Blanchard (1913), } \\
\text { Rabot (1914/1915), } \\
\text { Le Roy Ladurie (1967), } \\
\text { Wetter (1987), } \\
\text { Nussbaumer et al. (2007) }\end{array}$ \\
\hline 1605 & Written source & Local & $\begin{array}{l}\text { Archives municipales de } \\
\text { Chamonix-Mont-Blanc }\end{array}$ & $\begin{array}{l}\text { Mougin (1912), } \\
\text { Kinzl (1932) }\end{array}$ \\
\hline 1606 & Written source & F. de Sales & & Mollier (2000) \\
\hline 1610 & Written source & $\begin{array}{l}\text { Local/ } \\
\text { P. Mougin }\end{array}$ & $\begin{array}{l}\text { Archives municipales de } \\
\text { Chamonix-Mont-Blanc }\end{array}$ & Mougin (1912) \\
\hline 1616 & Written source & N. Grandjean & $\begin{array}{l}\text { Archives municipales de } \\
\text { Chamonix-Mont-Blanc }\end{array}$ & $\begin{array}{l}\text { Mougin (1912), } \\
\text { Le Roy Ladurie (1967) }\end{array}$ \\
\hline $1643(?)$ & Written source & $\begin{array}{l}\text { Local/ } \\
\text { P. Mougin }\end{array}$ & $\begin{array}{l}\text { Archives municipales de } \\
\text { Chamonix-Mont-Blanc }\end{array}$ & $\begin{array}{l}\text { Mougin (1912), } \\
\text { Vallot et al. (1925), } \\
\text { Kinzl (1932), } \\
\text { Le Roy Ladurie (1967) }\end{array}$ \\
\hline 1644 & Written source & C.-A. de Sales & $\begin{array}{l}\text { Archives municipales de } \\
\text { Chamonix-Mont-Blanc }\end{array}$ & Mougin (1912) \\
\hline
\end{tabular}


Table 2 (continued)

\begin{tabular}{|c|c|c|c|c|}
\hline Date & $\begin{array}{l}\text { Type of } \\
\text { document }\end{array}$ & $\begin{array}{l}\text { Observer/ } \\
\text { author }\end{array}$ & Owner & Literature \\
\hline 1664 & Written source & $\begin{array}{l}\text { Local/ } \\
\text { P. Mougin }\end{array}$ & $\begin{array}{l}\text { Archives municipales de } \\
\text { Chamonix-Mont-Blanc }\end{array}$ & Mougin (1912) \\
\hline 1669 & Written source & Local & $\begin{array}{l}\text { Archives départementales } \\
\text { de la Haute-Savoie, } \\
\text { Annecy }\end{array}$ & Le Roy Ladurie (1967) \\
\hline 1679 & Written source & Local & $\begin{array}{l}\text { Archives départementales } \\
\text { de la Haute-Savoie, } \\
\text { Annecy }\end{array}$ & Le Roy Ladurie (1967) \\
\hline $1685(?)$ & Written source & $\begin{array}{l}\text { Local/ } \\
\text { P. Mougin }\end{array}$ & & Mougin (1912) \\
\hline $1700(?)$ & Written source & $\begin{array}{l}\text { Local/ } \\
\text { P. Mougin }\end{array}$ & & Mougin (1912) \\
\hline 1712 & Written source & $\begin{array}{l}\text { Local/ } \\
\text { P. Mougin }\end{array}$ & $\begin{array}{l}\text { Archives municipales de } \\
\text { Chamonix-Mont-Blanc }\end{array}$ & Mougin (1912) \\
\hline 1730 & Map (manuscript) & $\begin{array}{l}\text { (Victor- } \\
\text { Amédée II) }\end{array}$ & $\begin{array}{l}\text { Archives départementales } \\
\text { de la Haute-Savoie, } \\
\text { Annecy }\end{array}$ & $\begin{array}{l}\text { Mougin (1912), } \\
\text { Le Roy Ladurie (1967) }\end{array}$ \\
\hline 1742 & Print & P. Martel & & $\begin{array}{l}\text { Martel (1744), } \\
\text { Le Roy Ladurie (1967) }\end{array}$ \\
\hline 1742 & Map & P. Martel & & $\begin{array}{l}\text { Martel (1744), } \\
\text { Le Roy Ladurie (1967) }\end{array}$ \\
\hline $1760(?)$ & Written source & $\begin{array}{l}\text { H.-B. de } \\
\text { Saussure }\end{array}$ & & Le Roy Ladurie (1967) \\
\hline $\begin{array}{l}21-42 \\
\text { July } 1770\end{array}$ & Drawing & W. Pars & British Museum, London & Wilton (1979) \\
\hline 1772 & Written source & A.-C. Bordier & & Bordier (1773) \\
\hline $1773(?)$ & Print & M. T. Bourrit & Bibliothèque de Genève & $\begin{array}{l}\text { Bourrit (1773), } \\
\text { Mougin (1912), } \\
\text { Priuli and Garin } \\
\quad(1985)\end{array}$ \\
\hline $1773(?)$ & Written source & M. T. Bourrit & & Bourrit (1773) \\
\hline 1774 & Written source & M. T. Bourrit & & $\begin{array}{l}\text { Mougin (1912), } \\
\text { Le Roy Ladurie (1967) }\end{array}$ \\
\hline $\begin{array}{l}1774- \\
1780(?)\end{array}$ & Print & M. T. Bourrit & Bibliothèque de Genève & \\
\hline $\begin{array}{l}1774- \\
1780(?)\end{array}$ & Print & M. T. Bourrit & $\begin{array}{l}\text { Schweizerische } \\
\text { Nationalbibliothek, } \\
\text { Bern }\end{array}$ & de Saussure (1796) \\
\hline 1776 & Written source & W. Coxe & & $\begin{array}{l}\text { Forel (1889), } \\
\quad \text { Mougin (1912) }\end{array}$ \\
\hline 1777 & Print & F. Jalabert & $\begin{array}{l}\text { Zentralbibliothek Zürich, } \\
\text { Graphische Sammlung }\end{array}$ & \\
\hline 1778 & Written source & $\begin{array}{l}\text { H.-B. de } \\
\text { Saussure }\end{array}$ & & $\begin{array}{l}\text { de Saussure (1779), } \\
\text { Wetter (1987) }\end{array}$ \\
\hline $1779(?)$ & Map & M.-A. Pictet & $\begin{array}{l}\text { Schweizerische } \\
\text { Nationalbibliothek, Bern }\end{array}$ & de Saussure (1779) \\
\hline 1780 & Print & C. L. Hackert & $\begin{array}{l}\text { Schweizerische } \\
\text { Nationalbibliothek, Bern }\end{array}$ & \\
\hline 1780 & Written source & W. Coxe & & $\begin{array}{l}\text { Coxe }(1789), \\
\text { Mougin (1912) }\end{array}$ \\
\hline
\end{tabular}


Table 2 (continued)

\begin{tabular}{|c|c|c|c|c|}
\hline Date & $\begin{array}{l}\text { Type of } \\
\text { document }\end{array}$ & $\begin{array}{l}\text { Observer/ } \\
\text { author }\end{array}$ & Owner & Literature \\
\hline $\begin{array}{l}5 \text { August } \\
1785\end{array}$ & Drawing & $\begin{array}{l}\text { H. C. Escher } \\
\text { von der Linth }\end{array}$ & Private collection & Solar (1974) \\
\hline $1786(?)$ & Map & M.-A. Pictet & $\begin{array}{l}\text { Schweizerische } \\
\text { Nationalbibliothek, Bern }\end{array}$ & de Saussure (1786) \\
\hline $1787(?)$ & Print & $\begin{array}{c}\text { J.-F. Albanis } \\
\text { Beaumont }\end{array}$ & Bibliothèque de Genève & \\
\hline $\begin{array}{r}1787 / \\
1790\end{array}$ & Print & C. von Mechel & $\begin{array}{l}\text { Schweizerische } \\
\text { Nationalbibliothek, Bern }\end{array}$ & Mougin (1912) \\
\hline $1787(?)$ & Relief & C.-F. Exchaquet & $\begin{array}{l}\text { Swiss Alpine Club (SAC), } \\
\text { Genevese section }\end{array}$ & \\
\hline $1790(?)$ & Drawing & J.-P. Linck & $\begin{array}{l}\text { Musée d'art et d'histoire, } \\
\text { Genève }\end{array}$ & \\
\hline $1790(?)$ & Map & C.-F. Exchaquet & $\begin{array}{l}\text { Zentralbibliothek Zürich, } \\
\text { Kartensammlung }\end{array}$ & $\begin{array}{l}\text { Aliprandi and } \\
\text { Aliprandi (2007) }\end{array}$ \\
\hline 1794 & Print & S. Smith & & Mollier (2000) \\
\hline $\begin{array}{r}1797- \\
1799\end{array}$ & Map & J.-B. Raymond & $\begin{array}{l}\text { Zentralbibliothek Zürich, } \\
\text { Kartensammlung }\end{array}$ & $\begin{array}{l}\text { Aliprandi and } \\
\text { Aliprandi (2007) }\end{array}$ \\
\hline 1798 & Gouache & M.-T. Bourrit & $\begin{array}{l}\text { Swiss Alpine Club (SAC), } \\
\text { Genevese section }\end{array}$ & \\
\hline 1798 & Print & J.-A. Linck & $\begin{array}{l}\text { Graphische Sammlung } \\
\text { der ETH Zürich }\end{array}$ & Bouchardy (1986) \\
\hline 1799 & Oil painting & J.-A. Linck & $\begin{array}{l}\text { Conservatoire d'art et } \\
\text { d'histoire (CAH), } \\
\text { Annecy, Collection } \\
\text { Paul Payot }\end{array}$ & Vellozzi (1990) \\
\hline 1800 & Map & $\begin{array}{l}\text { J. R. Meyer/ } \\
\text { J. H. Weiss }\end{array}$ & $\begin{array}{l}\text { Zentralbibliothek Zürich, } \\
\text { Kartensammlung }\end{array}$ & \\
\hline $1800(?)$ & Relief & F. R. Hassler & $\begin{array}{l}\text { Museum of the American } \\
\text { Philosophical Society, } \\
\text { Philadelphia }\end{array}$ & Rickenbacher (2007) \\
\hline 1802 & Oil painting & W. Delamotte & $\begin{array}{l}\text { Musée-Château } \\
\text { (Beaux-Arts), Annecy }\end{array}$ & \\
\hline 1802 & Drawing & J. M. W. Turner & British Museum, London & \\
\hline $\begin{array}{l}1807 \\
(1806)\end{array}$ & Map & $\begin{array}{l}\text { H. C. Escher } \\
\text { von der Linth/ } \\
\text { M.-A. Pictet }\end{array}$ & $\begin{array}{l}\text { Zentralbibliothek Zürich, } \\
\text { Kartensammlung }\end{array}$ & $\begin{array}{l}\text { Pictet et al. (1807), } \\
\text { Brandenberger } \\
(2002)\end{array}$ \\
\hline 1811 & Written source & S. Birmann & $\begin{array}{l}\text { Schweizerische } \\
\text { Nationalbibliothek, Bern }\end{array}$ & Birmann (1826) \\
\hline $\begin{array}{c}15 \text { July } \\
1812\end{array}$ & Drawing & C. Ritter & & Ritter (2008) \\
\hline $\begin{array}{r}1812- \\
1818\end{array}$ & Written source & $\begin{array}{l}\text { Local/ } \\
\text { F.-A. Forel }\end{array}$ & & Forel (1889) \\
\hline 1813 & Gouache & J.-A. Linck & Private collection & \\
\hline $1815(?)$ & Drawing & Anonymous & & Mollier (2000) \\
\hline 1815 & Print & M. G. Lory & $\begin{array}{l}\text { Schweizerische } \\
\text { Nationalbibliothek, Bern }\end{array}$ & $\begin{array}{l}\text { Priuli and Garin } \\
\quad(1985)\end{array}$ \\
\hline 1816 & Drawing & J. J. Calutta & & Mollier (2000) \\
\hline 1816 & Drawing & J.-A. Linck & & Mollier (2000) \\
\hline $\begin{array}{l}8 \text { August } \\
1816 \\
\end{array}$ & Drawing & $\begin{array}{l}\text { H. C. Escher } \\
\text { von der Linth }\end{array}$ & $\begin{array}{l}\text { Graphische Sammlung } \\
\text { der ETH Zürich }\end{array}$ & \\
\hline
\end{tabular}


Table 2 (continued)

\begin{tabular}{|c|c|c|c|c|}
\hline$\overline{\text { Date }}$ & $\begin{array}{l}\text { Type of } \\
\text { document }\end{array}$ & $\begin{array}{l}\text { Observer/ } \\
\text { author }\end{array}$ & Owner & Literature \\
\hline 1816 & Written source & $\begin{array}{l}\text { H. C. Escher } \\
\text { von der Linth }\end{array}$ & $\begin{array}{l}\text { ETH-Bibliothek Zürich, } \\
\text { Wissenschaftshistorische } \\
\text { Sammlungen }\end{array}$ & \\
\hline $1817(?)$ & Drawing & J.-A. Linck & Private collection & $\begin{array}{l}\text { Dobiaschofsky } \\
\text { Auktionen (2009) }\end{array}$ \\
\hline $1818(?)$ & Drawing (5) & J.-A. Linck & $\begin{array}{l}\text { CAH, Annecy, } \\
\text { Collection Paul Payot }\end{array}$ & Vellozzi (1990) \\
\hline 1817 & Written source & S. Birmann & $\begin{array}{l}\text { Schweizerische } \\
\text { Nationalbibliothek, Bern }\end{array}$ & Birmann (1826) \\
\hline 1818 & Written source & $\begin{array}{l}\text { A. Balmat/ } \\
\text { A. de Luc/ } \\
\text { V. Payot/ } \\
\text { E. Viollet-le Duc }\end{array}$ & & $\begin{array}{l}\text { Viollet-le Duc (1876), } \\
\text { Forel (1889), } \\
\text { Mougin (1912), } \\
\text { Le Roy Ladurie } \\
\quad(1967)\end{array}$ \\
\hline 1819 & Written source & S. Birmann & $\begin{array}{l}\text { Schweizerische } \\
\text { Nationalbibliothek, Bern }\end{array}$ & Birmann (1826) \\
\hline $1820(?)$ & Drawing & $\begin{array}{l}\text { Anonymous } \\
\text { (English school) }\end{array}$ & $\begin{array}{l}\text { Alpine Club, Picture } \\
\text { Archive Dr Warren, } \\
\text { London }\end{array}$ & \\
\hline $1820(?)$ & Print & J. Dubois & & Mollier (2000) \\
\hline $\begin{array}{l}1820 / \\
1822\end{array}$ & Written source & A. de Luc & & $\begin{array}{l}\text { de Luc (1839), } \\
\text { Mougin (1912) }\end{array}$ \\
\hline 1823 & Drawing (4) & S. Birmann & $\begin{array}{l}\text { Kunstmuseum Basel, } \\
\text { Kupferstichkabinett }\end{array}$ & Birmann (1826) \\
\hline 1823 & Print (4) & S. Birmann & $\begin{array}{l}\text { Schweizerische } \\
\text { Nationalbibliothek, Bern }\end{array}$ & Birmann (1826) \\
\hline 1823 & $\begin{array}{l}\text { Map } \\
\quad \text { (manuscript) }\end{array}$ & F. Muletti & $\begin{array}{l}\text { Istituto Geografico } \\
\text { Militare, Firenze }\end{array}$ & $\begin{array}{l}\text { Aliprandi and } \\
\text { Aliprandi (2007) }\end{array}$ \\
\hline $\begin{array}{l}1824 \\
(1812)\end{array}$ & Relief & K. W. Kummer & $\begin{array}{l}\text { Bibliothèque nationale } \\
\text { de France, Paris }\end{array}$ & Ritter (2008) \\
\hline $1825(?)$ & Gouache & J. Dubois & $\begin{array}{l}\text { CAH, Annecy, } \\
\text { Collection Paul Payot }\end{array}$ & \\
\hline $1825(?)$ & Print & J. Dubois & $\begin{array}{l}\text { Zentralbibliothek Zürich, } \\
\text { Graphische Sammlung }\end{array}$ & \\
\hline 1827 & Print & J.-L.-F. Villeneuve & & Mollier (2000) \\
\hline 1829 & Drawing (3) & E. Backhouse & $\begin{array}{l}\text { Musée d'art et d'histoire, } \\
\text { Genève }\end{array}$ & \\
\hline 1829 & Map & F.-J. Pictet & $\begin{array}{l}\text { Zentralbibliothek Zürich, } \\
\text { Kartensammlung }\end{array}$ & \\
\hline 1835 & Written source & $\begin{array}{l}\text { Local/V. Payot/ } \\
\text { E. Viollet-le Duc }\end{array}$ & & $\begin{array}{l}\text { Viollet-le Duc (1876), } \\
\text { Payot (1887) }\end{array}$ \\
\hline $1840(?)$ & Print & I.-L. Deroy & Bibliothèque de Genève & Mollier (2000) \\
\hline $1840(?)$ & Print & N. M. J. Chapuy & & Mollier (2000) \\
\hline 1840 & Map & L. Rendu & & $\begin{array}{l}\text { Rendu (1840), } \\
\text { Aliprandi and } \\
\text { Aliprandi (2007) }\end{array}$ \\
\hline 1842 & Drawing & J. Ruskin & $\begin{array}{l}\text { CAH, Annecy, } \\
\text { Collection Paul Payot }\end{array}$ & Hélard (2005) \\
\hline $1842(?)$ & Drawing & R. Weinmann & $\begin{array}{l}\text { Museum zu Allerheiligen, } \\
\text { Schaffhausen }\end{array}$ & Wetter (1987) \\
\hline
\end{tabular}


Table 2 (continued)

\begin{tabular}{|c|c|c|c|c|}
\hline Date & $\begin{array}{l}\text { Type of } \\
\text { document }\end{array}$ & $\begin{array}{l}\text { Observer/ } \\
\text { author }\end{array}$ & Owner & Literature \\
\hline 1845 & Written source & A. Balmat & & Forel (1889) \\
\hline $1848(1834)$ & Oil painting & $\begin{array}{l}\text { L. F. Schnorr } \\
\text { von Carolsfeld }\end{array}$ & $\begin{array}{l}\text { Österreichische Galerie } \\
\text { Belvedere, Wien }\end{array}$ & \\
\hline 1850 & Oil painting & J. Guedy & $\begin{array}{l}\text { CAH, Annecy, } \\
\text { Collection Paul Payot }\end{array}$ & \\
\hline $\begin{array}{r}1839- \\
1852\end{array}$ & Drawing (2) & A. Winterlin & $\begin{array}{l}\text { Kunstmuseum Basel, } \\
\text { Kupferstichkabinett }\end{array}$ & \\
\hline $1850(?)$ & Print & G. Loppé & $\begin{array}{l}\text { CAH, Annecy, } \\
\text { Collection Paul Payot }\end{array}$ & Mollier (2000) \\
\hline $1850(?)$ & Map & J. D. Forbes & $\begin{array}{l}\text { Zentralbibliothek Zürich, } \\
\text { Kartensammlung }\end{array}$ & Forbes (1855) \\
\hline 1850 & Written source & V. Payot & & Mougin (1912) \\
\hline 1854 & Written source & V. Payot & & $\begin{array}{l}\text { Mougin (1912), } \\
\text { Kinzl (1932) }\end{array}$ \\
\hline $1855(?)$ & Drawing & E. T. Coleman & $\begin{array}{l}\text { CAH, Annecy, } \\
\text { Collection Paul Payot }\end{array}$ & \\
\hline 1856 & Map & $\begin{array}{l}\text { (Corpo Reale di } \\
\text { Stato Maggiore) }\end{array}$ & $\begin{array}{l}\text { Zentralbibliothek Zürich, } \\
\text { Kartensammlung }\end{array}$ & \\
\hline 1856 & Written source & A. Balmat & & Forel (1889) \\
\hline $1859(?)$ & Drawing & A. Guesdon & & Vellozzi et al. (2002) \\
\hline $1859(?)$ & Print & A. Guesdon & & Vellozzi et al. (2002) \\
\hline 1859 & Photograph (2) & F. Martens & $\begin{array}{l}\text { Alpine Club Library, } \\
\text { London }\end{array}$ & \\
\hline $1860(1859)$ & Print (3) & $\begin{array}{l}\text { E. Ciceri, after } \\
\text { F. Martens }\end{array}$ & $\begin{array}{l}\text { Schweizerische } \\
\text { Nationalbibliothek, Bern }\end{array}$ & \\
\hline $1860(?)$ & Photograph & Bisson Frères & $\begin{array}{l}\text { Alpine Club Library, } \\
\text { London }\end{array}$ & $\begin{array}{l}\text { Chlumsky et al. } \\
\text { (1999) }\end{array}$ \\
\hline $\begin{array}{l}1860 \\
\quad(1857-1863)\end{array}$ & Photograph & Bisson Frères & $\begin{array}{l}\text { Alpine Club Library, } \\
\text { London }\end{array}$ & $\begin{array}{l}\text { Chlumsky et al. } \\
\text { (1999) }\end{array}$ \\
\hline $1861(?)$ & Map & G.-H. Dufour & $\begin{array}{l}\text { Geographisches Institut } \\
\text { der Universität Bern, } \\
\text { Kartensammlung }\end{array}$ & \\
\hline $1862(?)$ & Photograph & Bisson Frères & $\begin{array}{l}\text { Société française de } \\
\text { photographie, Paris }\end{array}$ & $\begin{array}{l}\text { Chlumsky et al. } \\
\text { (1999) }\end{array}$ \\
\hline 1862 & Photograph & A. Braun & $\begin{array}{l}\text { ETH-Bibliothek Zürich, } \\
\text { Bildarchiv }\end{array}$ & \\
\hline $\begin{array}{l}1863 \\
\quad(1857-1863)\end{array}$ & Photograph & Bisson Frères & $\begin{array}{l}\text { Alpine Club Library, } \\
\text { London }\end{array}$ & $\begin{array}{l}\text { Chlumsky et al. } \\
\text { (1999) }\end{array}$ \\
\hline 1863 & Photograph (2) & W. England & $\begin{array}{l}\text { Alpine Club Library, } \\
\text { London }\end{array}$ & \\
\hline 1863-1864 & Map & A. Adams-Reilly & $\begin{array}{l}\text { Zentralbibliothek Zürich, } \\
\text { Kartensammlung }\end{array}$ & \\
\hline $1863-1865$ & Map & J.-J. Mieulet & $\begin{array}{l}\text { Zentralbibliothek Zürich, } \\
\text { Kartensammlung }\end{array}$ & \\
\hline $1864(?)$ & Photograph & C. Soulier & $\begin{array}{l}\text { Médiathèque Valais, } \\
\text { Martigny }\end{array}$ & Hugger (2009) \\
\hline 1865 & Written source & V. Payot & & Mougin (1912) \\
\hline 1866 & Photograph & Anonymous & & Vivian (2001) \\
\hline 1866 & Written source & V. Payot & & Mougin (1912) \\
\hline 1867 & Written source & V. Payot & & Mougin (1912) \\
\hline
\end{tabular}


Table 2 (continued)

\begin{tabular}{|c|c|c|c|c|}
\hline Date & $\begin{array}{l}\text { Type of } \\
\text { document }\end{array}$ & $\begin{array}{l}\text { Observer/ } \\
\text { author }\end{array}$ & Owner & Literature \\
\hline $\begin{array}{l}6 \text { August } \\
1868\end{array}$ & Drawing & E. Viollet-le Duc & $\begin{array}{l}\text { Musée Lambinet, } \\
\text { Versailles }\end{array}$ & Frey (1988) \\
\hline $\begin{array}{l}5 \text { September } \\
1868\end{array}$ & Drawing & E. Viollet-le Duc & $\begin{array}{l}\text { Médiathèque de } \\
\text { l'architecture et } \\
\text { du patrimoine, Paris, } \\
\text { Fonds Viollet-le Duc }\end{array}$ & Gubler (1979) \\
\hline 1868 & Written source & V. Payot & & Mougin (1912) \\
\hline $\begin{array}{l}\text { 12 September } \\
1869\end{array}$ & Drawing & E. Viollet-le Duc & $\begin{array}{l}\text { Médiathèque de } \\
\text { l'architecture et } \\
\text { du patrimoine, Paris, } \\
\text { Fonds Viollet-le Duc }\end{array}$ & Gubler (1979) \\
\hline $1869(1863)$ & Map & J.-J. Mieulet & $\begin{array}{l}\text { Zentralbibliothek Zürich, } \\
\text { Kartensammlung }\end{array}$ & \\
\hline 1869 & Written source & Briquet & & Mougin (1912) \\
\hline 1870 & Written source & $\begin{array}{l}\text { A. Favre/ } \\
\text { Freundler }\end{array}$ & & Mougin (1912) \\
\hline 1871 & Written source & A. Favre & & Mougin (1912) \\
\hline July 1873 & Print & E. Viollet-le Duc & & $\begin{array}{l}\text { Viollet-le Duc } \\
\text { (1876) }\end{array}$ \\
\hline 3 July 1857 & Drawing & G. Loppé & Musée Alpin, Chamonix & \\
\hline 1874 & Drawing & J. Ruskin & $\begin{array}{l}\text { Alpine Club, } \\
\text { Picture Archive } \\
\text { Dr Warren, London }\end{array}$ & Hélard (2005) \\
\hline $1868-1875$ & Map & E. Viollet-le Duc & $\begin{array}{l}\text { Geographisches Institut } \\
\text { der Universität Bern, } \\
\text { Kartensammlung }\end{array}$ & $\begin{array}{l}\text { Viollet-le Duc } \\
\text { (1876), Mougin } \\
\text { (1910), Frey } \\
\text { (1988) }\end{array}$ \\
\hline 1874 & Written source & Briquet & & Mougin (1912) \\
\hline 1875 & Written source & A. Forel & & Mougin (1912) \\
\hline 1876 & Written source & A. Balmat & & $\begin{array}{l}\text { Forel (1889), } \\
\quad \text { Mougin (1912) }\end{array}$ \\
\hline 1878 & Written source & A. Forel & & Mougin (1912) \\
\hline 1879 & Written source & V. Payot & & Mougin (1912) \\
\hline 1880 & Written source & V. Payot & & Mougin (1912) \\
\hline 1881 & Written source & V. Payot & & Mougin (1912) \\
\hline 1882 & Written source & V. Payot & & Mougin (1912) \\
\hline 1883 & Written source & V. Payot & & Mougin (1912) \\
\hline $\begin{array}{l}20 \text { October } \\
1884\end{array}$ & Photograph & Tairraz & $\begin{array}{l}\text { ETH-Bibliothek Zürich, } \\
\text { Bildarchiv }\end{array}$ & \\
\hline 1884 & Written source & V. Payot & & Mougin (1912) \\
\hline $\begin{array}{l}20 \text { October } \\
1885\end{array}$ & Photograph & Tairraz & $\begin{array}{l}\text { ETH-Bibliothek Zürich, } \\
\text { Bildarchiv }\end{array}$ & \\
\hline 1885 & Written source & V. Payot & & Mougin (1912) \\
\hline $\begin{array}{l}10 \text { October } \\
1886\end{array}$ & Photograph & Tairraz & $\begin{array}{l}\text { ETH-Bibliothek Zürich, } \\
\text { Bildarchiv }\end{array}$ & \\
\hline 1886 & Photograph & $\begin{array}{l}\text { Charnaux } \\
\text { Frères }\end{array}$ & Bibliothèque de Genève & \\
\hline 1886 & Written source & V. Payot & & Mougin (1912) \\
\hline $\begin{array}{l}22 \text { October } \\
1887\end{array}$ & Photograph (2) & Tairraz & $\begin{array}{l}\text { ETH-Bibliothek Zürich, } \\
\text { Bildarchiv }\end{array}$ & \\
\hline 1887 & Written source & V. Payot & & Mougin (1912) \\
\hline
\end{tabular}


Table 2 (continued)

\begin{tabular}{|c|c|c|c|c|}
\hline Date & $\begin{array}{l}\text { Type of } \\
\text { document }\end{array}$ & $\begin{array}{l}\text { Observer/ } \\
\text { author }\end{array}$ & Owner & Literature \\
\hline 8 October 1888 & Photograph & Tairraz & $\begin{array}{l}\text { ETH-Bibliothek Zürich, } \\
\text { Bildarchiv }\end{array}$ & \\
\hline 1888 & Written source & V. Payot & & $\begin{array}{l}\text { Forel (1889), } \\
\quad \text { Mougin (1912) }\end{array}$ \\
\hline $\begin{array}{l}24 \text { September } \\
1889\end{array}$ & Photograph & Tairraz & $\begin{array}{l}\text { ETH-Bibliothek Zürich, } \\
\text { Bildarchiv }\end{array}$ & \\
\hline 1889 & Written source & $\begin{array}{c}\text { A. Balmat/ } \\
\text { V. Payot }\end{array}$ & & $\begin{array}{l}\text { Forel (1889), } \\
\quad \text { Mougin (1912) }\end{array}$ \\
\hline October 1890 & Photograph & Tairraz & $\begin{array}{l}\text { ETH-Bibliothek Zürich, } \\
\text { Bildarchiv }\end{array}$ & \\
\hline 1890 & Written source & V. Payot & & Mougin (1912) \\
\hline October 1891 & Photograph (2) & Tairraz & $\begin{array}{l}\text { ETH-Bibliothek Zürich, } \\
\text { Bildarchiv }\end{array}$ & \\
\hline 1891 & Written source & V. Payot & & Mougin (1912) \\
\hline September 1892 & Photograph & Tairraz & $\begin{array}{l}\text { ETH-Bibliothek Zürich, } \\
\text { Bildarchiv }\end{array}$ & \\
\hline October 1892 & Photograph & Tairraz & $\begin{array}{l}\text { ETH-Bibliothek Zürich, } \\
\text { Bildarchiv }\end{array}$ & \\
\hline 1892 & Photograph (3) & Anonymous & $\begin{array}{l}\text { ETH-Bibliothek Zürich, } \\
\text { Bildarchiv }\end{array}$ & \\
\hline 1892 & Written source & P. Mougin & & Mougin (1912) \\
\hline October 1893 & Photograph & Tairraz & $\begin{array}{l}\text { ETH-Bibliothek Zürich, } \\
\text { Bildarchiv }\end{array}$ & \\
\hline 1893 & Written source & P. Mougin & & Mougin (1912) \\
\hline October 1894 & Photograph & Tairraz & $\begin{array}{l}\text { ETH-Bibliothek Zürich, } \\
\text { Bildarchiv }\end{array}$ & \\
\hline 1894 & Written source & P. Mougin & & Mougin (1912) \\
\hline October 1895 & Photograph & Tairraz & $\begin{array}{l}\text { ETH-Bibliothek Zürich, } \\
\text { Bildarchiv }\end{array}$ & \\
\hline 1895 & Photograph & $\begin{array}{l}\text { Photochrom } \\
\text { Zürich }\end{array}$ & Private collection & Arqué et al. (2009) \\
\hline 1891-1914 & $\begin{array}{l}\text { Photograph } \\
\quad(\sim 12)\end{array}$ & $\begin{array}{l}\text { Photochrom } \\
\text { Zürich }\end{array}$ & $\begin{array}{c}\text { Zentralbibliothek Zürich, } \\
\text { Graphische Sammlung }\end{array}$ & Arqué et al. (2009) \\
\hline 1895 & Written source & P. Mougin & & Mougin (1912) \\
\hline October 1896 & Photograph & Tairraz & $\begin{array}{l}\text { ETH-Bibliothek Zürich, } \\
\text { Bildarchiv }\end{array}$ & \\
\hline 1896 & Map & $\begin{array}{l}\text { A. Barbey/ } \\
\text { X. Imfeld/ } \\
\text { L. Kurz }\end{array}$ & $\begin{array}{l}\text { Zentralbibliothek Zürich, } \\
\text { Kartensammlung }\end{array}$ & $\begin{array}{l}\text { Cavelti Hammer } \\
\text { et al. (2006) }\end{array}$ \\
\hline 1896 & Written source & V. Payot & & Mougin (1910) \\
\hline September 1897 & Photograph & Tairraz & $\begin{array}{l}\text { ETH-Bibliothek Zürich, } \\
\text { Bildarchiv }\end{array}$ & \\
\hline October 1898 & Photograph & Tairraz & $\begin{array}{l}\text { ETH-Bibliothek Zürich, } \\
\text { Bildarchiv }\end{array}$ & \\
\hline October 1900 & Photograph & Tairraz & $\begin{array}{l}\text { ETH-Bibliothek Zürich, } \\
\text { Bildarchiv }\end{array}$ & \\
\hline $1903(?)$ & $\begin{array}{l}\text { Photograph } \\
\text { Frères }\end{array}$ & Jullien & $\begin{array}{l}\text { ETH-Bibliothek Zürich, } \\
\text { Bildarchiv }\end{array}$ & \\
\hline 3 September 1904 & Photograph & P. Mougin & & Mougin (1910) \\
\hline
\end{tabular}


Table 2 (continued)

\begin{tabular}{|c|c|c|c|c|}
\hline Date & $\begin{array}{l}\text { Type of } \\
\text { document }\end{array}$ & $\begin{array}{l}\text { Observer/ } \\
\text { author }\end{array}$ & Owner & Literature \\
\hline 1904 & Written source & P. Mougin & & Mougin (1912) \\
\hline 1905 & Written source & P. Mougin & & Mougin (1912) \\
\hline 14 June 1906 & Photograph (3) & P. Mougin & $\begin{array}{l}\text { ETH-Bibliothek Zürich, } \\
\text { Bildarchiv }\end{array}$ & \\
\hline 23 August 1906 & Map & $\begin{array}{l}\text { H. Vallot/ } \\
\text { J. Vallot }\end{array}$ & $\begin{array}{l}\text { Zentralbibliothek Zürich, } \\
\text { Kartensammlung }\end{array}$ & Vivian (1986) \\
\hline 1906 & Written source & P. Mougin & & Mougin (1912) \\
\hline 28 June 1907 & Photograph & P. Mougin & & Mougin (1910) \\
\hline 1907 & Written source & P. Mougin & & Mougin (1912) \\
\hline 16 July 1908 & Photograph & P. Mougin & & Mougin (1910) \\
\hline 1908 & Written source & P. Mougin & & Mougin (1912) \\
\hline 1909 & Written source & P. Mougin & & Mougin (1912) \\
\hline 21 July 1910 & Photograph & P. Mougin & & Mougin (1912) \\
\hline 1910 & Written source & P. Mougin & & Mougin (1912) \\
\hline 1911 & Written source & P. Mougin & & Mougin (1912) \\
\hline 1912 & Written source & P. Mougin & & Mougin (1925) \\
\hline 1913 & Written source & P. Mougin & & Mougin (1925) \\
\hline 1914 & Photograph & Tairraz & $\begin{array}{l}\text { ETH-Bibliothek Zürich, } \\
\text { Bildarchiv }\end{array}$ & \\
\hline 1914 & Written source & P. Mougin & & Mougin (1925) \\
\hline 1915 & Photograph & Tairraz & $\begin{array}{l}\text { ETH-Bibliothek Zürich, } \\
\text { Bildarchiv }\end{array}$ & \\
\hline 1915 & Written source & P. Mougin & & Mougin (1925) \\
\hline 1916 & Photograph (2) & Tairraz & $\begin{array}{l}\text { ETH-Bibliothek Zürich, } \\
\text { Bildarchiv }\end{array}$ & \\
\hline 1916 & Written source & P. Mougin & & Mougin (1925) \\
\hline September 1917 & Photograph (2) & Tairraz & $\begin{array}{l}\text { ETH-Bibliothek Zürich, } \\
\text { Bildarchiv }\end{array}$ & \\
\hline 1917 & Written source & P. Mougin & & Mougin (1925) \\
\hline September 1918 & Photograph & Tairraz & $\begin{array}{l}\text { ETH-Bibliothek Zürich, } \\
\text { Bildarchiv }\end{array}$ & \\
\hline 1918 & Written source & P. Mougin & & Mougin (1925) \\
\hline September 1919 & Photograph & Tairraz & $\begin{array}{l}\text { ETH-Bibliothek Zürich, } \\
\text { Bildarchiv }\end{array}$ & \\
\hline 1919 & Written source & P. Mougin & & Mougin (1925) \\
\hline September 1920 & Photograph & Tairraz & & Mougin (1925) \\
\hline 1920 & Written source & P. Mougin & & Mougin (1925) \\
\hline September 1921 & Photograph (2) & Tairraz & $\begin{array}{l}\text { ETH-Bibliothek Zürich, } \\
\text { Bildarchiv }\end{array}$ & \\
\hline September 1923 & Photograph (3) & Tairraz & $\begin{array}{l}\text { ETH-Bibliothek Zürich, } \\
\text { Bildarchiv }\end{array}$ & \\
\hline September 1924 & Photograph (3) & Tairraz & $\begin{array}{l}\text { ETH-Bibliothek Zürich, } \\
\text { Bildarchiv }\end{array}$ & \\
\hline September 1925 & Photograph (3) & Tairraz & $\begin{array}{l}\text { ETH-Bibliothek Zürich, } \\
\text { Bildarchiv }\end{array}$ & \\
\hline September 1926 & Photograph (2) & Tairraz & $\begin{array}{l}\text { ETH-Bibliothek Zürich, } \\
\text { Bildarchiv }\end{array}$ & \\
\hline 23 August 1927 & Photograph (2) & Rochebrune & $\begin{array}{l}\text { ETH-Bibliothek Zürich, } \\
\text { Bildarchiv }\end{array}$ & \\
\hline
\end{tabular}


Table 2 (continued)

\begin{tabular}{|c|c|c|c|c|}
\hline Date & $\begin{array}{l}\text { Type of } \\
\text { document }\end{array}$ & $\begin{array}{l}\text { Observer/ } \\
\text { author }\end{array}$ & Owner & Literature \\
\hline September 1927 & Photograph (2) & Tairraz & $\begin{array}{l}\text { ETH-Bibliothek Zürich, } \\
\text { Bildarchiv }\end{array}$ & \\
\hline 9 September 1928 & Photograph (2) & Rochebrune & $\begin{array}{l}\text { ETH-Bibliothek Zürich, } \\
\text { Bildarchiv }\end{array}$ & \\
\hline September 1928 & Photograph (2) & Tairraz & $\begin{array}{l}\text { ETH-Bibliothek Zürich, } \\
\text { Bildarchiv }\end{array}$ & \\
\hline September 1929 & Photograph (2) & Tairraz & $\begin{array}{l}\text { ETH-Bibliothek Zürich, } \\
\text { Bildarchiv }\end{array}$ & \\
\hline September 1930 & Photograph (2) & Tairraz & $\begin{array}{l}\text { ETH-Bibliothek Zürich, } \\
\text { Bildarchiv }\end{array}$ & \\
\hline September 1931 & Photograph (2) & Tairraz & $\begin{array}{l}\text { ETH-Bibliothek Zürich, } \\
\text { Bildarchiv }\end{array}$ & \\
\hline September 1932 & Photograph (2) & Tairraz & $\begin{array}{l}\text { ETH-Bibliothek Zürich, } \\
\text { Bildarchiv }\end{array}$ & \\
\hline September 1933 & Photograph (2) & Tairraz & $\begin{array}{l}\text { ETH-Bibliothek Zürich, } \\
\text { Bildarchiv }\end{array}$ & \\
\hline September 1938 & Photograph (2) & Tairraz & $\begin{array}{l}\text { ETH-Bibliothek Zürich, } \\
\text { Bildarchiv }\end{array}$ & \\
\hline 5 September 1979 & $\begin{array}{l}\text { Aerial } \\
\text { photograph }\end{array}$ & $\begin{array}{l}\text { Institut géographique } \\
\text { national }\end{array}$ & IGN, Paris & \\
\hline 25 July 1999 & Satellite image & Landsat & $\begin{array}{c}\text { Global Land Cover } \\
\text { Facility (GLCF) }\end{array}$ & \\
\hline 1 August 2001 & Aerial photograph & $\begin{array}{l}\text { Institut géographique } \\
\text { national }\end{array}$ & IGN, Paris & \\
\hline
\end{tabular}

Systematic frontal measurements since 1921 (written sources; LGGE, Grenoble) are not included in the list. The list is not exhaustive

\section{References}

Aliprandi L, Aliprandi G (2007) Les Grandes Alpes dans la cartographie 1482-1885. La cartographie des grands massifs alpins. Vol. 2. Libris, Grenoble, $383 \mathrm{pp}$

Arqué S, Boulouch N, Jezierski JV, Weber B (2009) Voyage en couleur, photochromie (1876-1914). Catalogue. Exposition à la Bibliothèque Forney, Paris, 27.01.-16.04.2009. Paris bibliothèques, Eyrolles, Paris, 192 pp

Baud D, Castiglioni C, Remacle C (2008) Le Cadastre Sarde: réglements, procédures et pratiques administratives. In: Longhi A (ed) Cadastres et territoires-Catasti e territori. Alinea, Firenze, pp $96-121$

Birmann S (1826) Souvenirs de la vallée de Chamonix. Birmann et fils, Basel

Blanchard R (1913) La crue glaciaire dans les Alpes de Savoie au XVIIe siècle. Recueil de travaux de l'Institut de Géographie Alpine 1:443-454

Bordier A-C (1773) Voyage pitoresque aux glacières de Savoye. Fait en 1772. Caille, Genève, 303 pp

Bouchardy MP (1986) Jean-Antoine Linck (1766-1843)—paysagiste genevois. Mémoire de Licence (unpublished), Université de Genève, 101 pp

Bourrit MT (1773) Description des glacières, glaciers et amas de glace du Duché de Savoye. Bonnant, Genève, $136 \mathrm{pp}$

Brandenberger R (ed) (2002) Die ersten Panoramen der Alpen. Hans Conrad Escher von der Linth, Werkverzeichnis. Linth-Escher-Stiftung, Mollis, $452 \mathrm{pp}$

Casty C, Wanner H, Luterbacher J, Esper J, Böhm R (2005) Temperature and precipitation variability in the European Alps since 1500. Int J Climatol 25(14):1855-1880

Cavelti Hammer M, Spichig K, von Flüe N, Germann T, Caminada P, Feldmann H-U, Glatthard T (2006) Xaver Imfeld 1853-1909. Meister der Alpentopografie. von Ah Druck, Sarnen, 191 pp 
Chlumsky M, Eskildsen U, Marbot B (1999) Die Brüder Bisson. Aufstieg und Fall eines Fotografenunternehmens im 19. Jahrhundert. Katalog zur gleichnamigen Ausstellung: Museum Folkwang, Essen, 07.02.-28.03.1999; Fotomuseum im Münchner Stadtmuseum, 11.04.-30.05.1999; Bibliothèque nationale de France, Paris, 15.06.-15.08.1999. Verlag der Kunst, Amsterdam, 232 pp

Cole-Dai J, David Ferris D, Lanciki A, Savarino J, Baroni M, Thiemens MH (2009) Cold decade (AD 1810-1819) caused by Tambora (1815) and another (1809) stratospheric volcanic eruption. Geophys Res Lett 36(22):L22703. doi:10.1029/2009GL040882

Corbel J, Le Roy Ladurie E (1963) Datation au C14 d'une moraine du Mont-Blanc. Rev Géogr Alp 51(1):173-175

Coxe W (1789) Travels in Switzerland in a series of letters to William Melmoth, 3 vols. Cadell, London

Cunningham FF (1990) James David Forbes. Pioneer Scottish glaciologist. Scottish Academic Press, Edinburgh, $329 \mathrm{pp}$

de Luc JA (1839) Note sur les glaciers des Alpes. Bibliothèque Universelle de Genève, Nouvelle Série 21:141-146

de Saussure H-B (1779) Voyages dans les Alpes. Tome 1. S. Fauche, Neuchâtel, 540 pp

de Saussure H-B (1786) Voyages dans les Alpes. Tome 2. Barde, Manget et Compagnie, Genève, $641 \mathrm{pp}$

de Saussure H-B (1796) Voyages dans les Alpes. Tome 4. L. Fauche-Borel, Neuchâtel, 594 pp

Dobiaschofsky Auktionen (2009) Auktion A-108, Katalog I. Schweizer Kunst. 15.05.2009. Auktionshaus Dobiaschofsky, Bern, 136 pp

Fischer EM, Luterbacher J, Zorita E, Tett SFB, Casty C, Wanner H (2007) European climate response to tropical volcanic eruptions over the last half millennium. Geophys Res Lett 34(5):L05707. doi:10.1029/2006GL027992

Forbes JD (1843) Travels through the Alps of Savoy and other parts of the Pennine chain with observations of the phenomena of glaciers. Adam and Charles Black, Edinburgh, 424 pp

Forbes JD (1855) Über die Gletscher-Welt im allgemeinen und die Gletscher des Mont-Blanc im besonderen. Petermann's Geogr Mitt 173-199

Forel F-A (1889) Les variations périodiques des glaciers des Alpes. 10ième rapport. Extrait du "Jahrbuch S.A.C."

Frey PA (ed) (1988) E. Viollet-le Duc et le massif du Mont-Blanc 1868-1879. Editions Payot, Lausanne, 160 pp

Gletscherberichte (1881-2009) Die Gletscher der Schweizer Alpen. Jahrbücher der Expertenkommission für Kryosphärenmessnetze der Akademie der Naturwissenschaften Schweiz (SCNAT). Versuchsanstalt für Wasserbau, Hydrologie und Glaziologie (VAW) der ETH, Zürich, No. 1-126. http://glaciology.ethz.ch/swiss-glaciers/

Grove JM (2004) Little ice ages: ancient and modern, 2nd edn, 2 vols. Routledge, London

Gubler J (ed) (1979) Viollet-le Duc. Centenaire de la mort à Lausanne. Catalogue. Exposition au Musée historique de l'Ancien-Evêché, 22.06.-30.09.1979, Lausanne, 293 pp

Guichonnet P (1955) Le cadastre savoyard de 1738 et son utilisation pour les recherches d'histoire et de géographie sociales. Rev Géogr Alp 43:255-298

Haeberli W, Hoelzle M (1995) Application of inventory data for estimating characteristics of and regional climatic-change effects on mountain glaciers: a pilot study with the European Alps. Ann Glaciol 21:206-212

Hélard A (2005) John Ruskin et les cathédrales de la terre. Guérin, Chamonix, 375 pp

Hoelzle M, Haeberli W, Dischl M, Peschke W (2003) Secular glacier mass balances derived from cumulative glacier length changes. Glob Planet Change 36(4):295-306

Hoelzle M, Chinn T, Stumm D, Paul F, Zemp M, Haeberli W (2007) The application of glacier inventory data for estimating past climate change effects on mountain glaciers: a comparison between the European Alps and the Southern Alps of New Zealand. Glob Planet Change 56(1-2):69-82

Holzhauser H, Zumbühl HJ (1996) To the history of the Lower Grindelwald Glacier during the last 2800 years - palaeosols, fossil wood and historical pictorial records-new results. Z Geomorphol N F Suppl bd 104:95-127

Holzhauser H, Magny M, Zumbühl HJ (2005) Glacier and lake-level variations in west-central Europe over the last 3500 years. Holocene 15(6):789-801

Hugger P (ed) (2009) Welten aus Fels und Eis. Alpine Fotografie in der Schweiz. Geschichte und Gegenwart. Verlag Neue Zürcher Zeitung, Zürich, 347 pp

Huss M, Bauder A, Funk M, Hock R (2008) Determination of the seasonal mass balance of four Alpine glaciers since 1865. J Geophys Res 113(F1):F01015. doi:10.1029/2007JF000803 
Huss M, Funk M, Ohmura A (2009) Strong Alpine glacier melt in the 1940s due to enhanced solar radiation. Geophys Res Lett 36(23):L23501. doi:10.1029/2009GL04078

Huss M, Hock R, Bauder R, Funk M (2010) 100-year mass changes in the Swiss Alps linked to the Atlantic Multidecadal Oscillation. Geophys Res Lett 37(10):L10501. doi:10.1029/ 2010GL042616

Imhof M (1998) Rock glaciers, Bernese Alps, western Switzerland. In: International permafrost association, data and information working group. National Snow and Ice Data Center (NSIDC)/World Data Center for Glaciology, University of Colorado, Boulder, CD-ROM

IPCC (2007) Climate change 2007: the physical science basis. In: Solomon S, Qin D, Manning M, Chen Z, Marquis M, Averyt KB, Tignor M, Miller HL (eds) Contribution of working group I to the fourth assessment report of the intergovernmental panel on climate change. Cambridge University Press, Cambridge and New York, 996 pp

Jacobeit J, Wanner H, Luterbacher J, Beck C, Philipp A, Sturm K (2003) Atmospheric circulation variability in the North-Atlantic-European area since the mid-seventeenth century. Clim Dyn 20(4):341-352

Jóhannesson T, Raymond CF, Waddington E (1989) Time-scale for adjustment of glaciers to changes in mass balance. J Glaciol 35(121):355-369

Kinzl H (1932) Die grössten nacheiszeitlichen Gletschervorstösse in den Schweizer Alpen und in der Mont Blanc-Gruppe. Z Gletsch kd Glazialgeol 20(4-5):269-397

Kirchhofer W, Sevruk B (1992) Mittlere jährliche korrigierte Niederschlagshöhen 1951-1980. In: Weingartner R, Spreafico M (eds) Hydrologischer Atlas der Schweiz. Bundesamt für Landestopographie, Bern-Wabern, Tafel 2.2

Kuhn M, Markl G, Kaser G, Nickus U, Obleitner F, Schneider H (1985) Fluctuations of climate and mass balance: different responses of two adjacent glaciers. Z Gletsch kd Glazialgeol 21(1-2): 409-416

Küttel M, Luterbacher J, Wanner H (2011) Multidecadal changes in winter circulation-climate relationship in Europe: frequency variations, within-type modifications, and long-term trends. Clim Dyn 36(5-6):957-972

Le Roy Ladurie E (1967) Histoire du climat depuis l'an mil. Flammarion, Paris, 379 pp

Linsbauer A, Paul F, Hoelzle M, Frey H, Haeberli W (2009) The Swiss Alps without glaciersa GIS-based modelling approach for reconstruction of glacier beds. In: Purves R, Gruber S, Hengl T, Straumann R (eds) Proceedings of Geomorphometry 2009. Department of Geography, University of Zurich, Zurich, pp 243-247. 31 August-2 September 2009

Luckman BH, Holdsworth G, Osborn GD (1993) Neoglacial glacier fluctuations in the Canadian Rockies. Quat Res 39(2):144-153

Luterbacher J, Dietrich D, Xoplaki E, Grosjean M, Wanner H (2004) European seasonal and annual temperature variability, trends, and extremes since 1500. Science 303(5663):14991503

Martel P (1744) An account of the glacieres or ice Alps in Savoy. In two letters. As laid before the Royal Society, London

Matthews JA, Briffa KR (2005) The 'Little Ice Age': re-evaluation of an evolving concept. Geogr Ann 87A(1):17-36

Mercanton PL (1916) Vermessungen am Rhonegletscher 1874-1915. Neue Denkschriften der Schweizerischen Naturforschenden Gesellschaft (SNG), Band 52. Kommissions-Verlag von Georg \& Co., Basel, 190 pp

Mollier C (2000) Du glacier du Mont-Blanc au glacier des Bossons. Editions Cabédita, Yens sur Morges, $132 \mathrm{pp}$

Mougin P (1910) Etudes glaciologiques. Savoie-Programme pour l'étude d'un grand glacier. Tome II. Imprimerie Nationale, Paris, $140 \mathrm{pp}$

Mougin P (1912) Etudes glaciologiques. Savoie-Pyrénées. Tome III. Imprimerie Nationale, Paris, $166 \mathrm{pp}$

Mougin P (1925) Etudes glaciologiques. Tome V. Imprimerie Nationale, Paris, $224 \mathrm{pp}$

Nemec J, Huybrechts P, Rybak O, Oerlemans J (2009) Reconstruction of the annual balance of Vadret da Morteratsch, Switzerland, since 1865. Ann Glaciol 50(50):126-134

Nesje A, Dahl SO (2003) The'Little Ice Age'—only temperature? Holocene 13(1):139-145

Nicolussi K (1990) Bilddokumente zur Geschichte des Vernagtferners im 17. Jahrhundert. Z Gletsch kd Glazialgeol 26(2):97-119

Nicolussi K (1994) Jahrringe und Massenbilanz. Dendroklimatische Rekonstruktion der Massenbilanzreihe des Hintereisferners bis zum Jahr 1400 mittels Pinus cembra-Reihen aus den Ötztaler Alpen, Tirol. Z Gletsch kd Glazialgeol 30(1-2):11-52 
Nussbaumer SU, Zumbühl HJ, Steiner D (2007) Fluctuations of the Mer de Glace (Mont Blanc area, France) AD 1500-2050: an interdisciplinary approach using new historical data and neural network simulations. Z Gletsch kd Glazialgeol 40(2005/2006):1-183

Nussbaumer SU, Steinhilber F, Trachsel M, Breitenmoser P, Beer J, Blass A, Grosjean M, Hafner A, Holzhauser H, Wanner H, Zumbühl HJ (2011) Alpine climate during the Holocene: a comparison between records of glaciers, lake sediments and solar activity. J Quat Sci 26. doi:10.1002/jqs. 1495

Nye JF (1965) The flow of a glacier in a channel of rectangular, elliptic or parabolic cross-section. J Glaciol 5(41):661-690

Oerlemans J (2001) Glaciers and climate change. A. A. Balkema Publishers, Lisse, 148 pp

Oerlemans J (2005) Extracting a climate signal from 169 glacier records. Science 308(5722):75-677

Oerlemans J, Reichert BK (2000) Relating glacier mass balance to meteorological data by using a seasonal sensitivity characteristic. J Glaciol 46(152):1-6

Paterson WSB (1994) The physics of glaciers. 3rd edn. Elsevier Science, Oxford, 481 pp

Paul F, Kääb A, Maisch M, Kellenberger T, Haeberli W (2004) Rapid disintegration of Alpine glaciers observed with satellite data. Geophys Res Lett 31(21):L21402. doi:10.1029/ 2004GL020816

Payot V (1887) Note sur la marche des glaciers de la vallée de Chamonix. Rev Savois 28:150-155

Pfister C (1999) Wetternachhersage. 500 Jahre Klimavariationen und Naturkatastrophen (14961995). Haupt, Bern/Stuttgart/Wien, 304 pp

Pfister C (2007) Climatic extremes, recurrent crises and witch hunts: strategies of European societies in coping with exogenous shocks in the late sixteenth and early seventeenth centuries. Mediev Hist J 10(1-2):33-73

Pictet M-A, Tingry P-F, Boissier H, de la Rive C-G (1807) Description et analyse d'une source thermale, découverte près St. Gervais, Département du Léman. Bibl Br Sci Arts 34(4): 378-394

Priuli G, Garin P (1985) Le Mont Blanc dans la gravure ancienne. Glénat, Grenoble, 385 pp

Rabot C (1914/1915) Récent travaux glaciaires dans les Alpes françaises. La Géographie 30: $257-268$

Rendu L (1840) Théorie des glaciers de la Savoie. Puthod, Chambéry, 158 pp

Reynaud L (1993) Glaciers of Europe - glaciers of the Alps: the French Alps. In: William Jr RS, Ferrigno JG (eds) Satellite image atlas of glaciers of the world. U S Geol Surv Prof Pap 1386E, E23-E36

Rickenbacher M (2007) Ferdinand Rudolf Hassler und die Vermessung der Schweiz 1791-1803. Cartogr Helv 36:11-25

Ritter C (2008) Montblanc. Geographisch-historisch-topographische Beschreibung zu K. W. Kummer's Stereorama oder Relief des Montblanc-Gebirges und dessen nächster Umgebung. Mahler Verlag, Stühlingen an der Wutach, $135 \mathrm{pp}$

Schmeits MJ, Oerlemans J (1997) Simulation of the historical variations in length of Unterer Grindelwaldgletscher, Switzerland. J Glaciol 43(143):152-164

Solar G (ed) (1974) Hans Conrad Escher von der Linth. Ansichten und Panoramen der Schweiz. Die Ansichten 1780-1822. Atlantis, Zürich, 368 pp

Steiner D, Pauling A, Nussbaumer SU, Nesje A, Luterbacher J, Wanner H, Zumbühl HJ (2008a) Sensitivity of European glaciers to precipitation and temperature-two case studies. Clim Change 90(4):413-441

Steiner D, Zumbühl HJ, Bauder A (2008b) Two Alpine glaciers over the past two centuries: a scientific view based on pictorial sources. In: Orlove B, Wiegandt E, Luckman BH (eds) Darkening peaks: glacier retreat, science, and society. University of California Press, Berkeley, pp 83-99

Steinhilber F, Beer J, Fröhlich C (2009) Total solar irradiance during the Holocene. Geophys Res Lett 36(19):L19704. doi:10.1029/2009GL040142

Vallot J (1900) Annales de l'observatoire météorologique, physique et glaciaire du Mont Blanc. Tome 4. Steinheil, Paris, $189 \mathrm{pp}$

Vallot C, Collet LW, Vallot J, Namur-Vallot M, Bonnier G, de Chabanolle L (1925) Description générale du massif du Mont-Blanc. Fischbacher, Paris, fascicule 1

Vellozzi MC (ed) (1990) Jean-Antoine Linck, peintre genevois. Paysages de Savoie au XVIIIe siècle. Catalogue. Exposition Conservatoire d'Art et d'Histoire, 14.07.-30.09.1990, Annecy, 88 pp

Vellozzi M-C, Vercken M-T, Guichonnet P, Joutard P, Lebailly H (2002) Mont-Blanc Conquête de l'imaginaire. Collection Paul Payot. La Fontaine de Siloé, Montmélian, 424 pp

Vincent C, Le Meur E, Six D, Funk M (2005) Solving the paradox of the end of the Little Ice Age in the Alps. Geophys Res Lett 32(9):L09706. doi:10.1029/2005GL022552 
Viollet-le Duc E (1876) Le massif du Mont Blanc. Etude sur sa constitution géodésique et géologique, sur ses transformations et sur l'état ancien et moderne de ses glaciers. Baudry, Paris, $280 \mathrm{pp}$

Vivian R (1986) L'épopée Vallot au Mont Blanc. Denoël, Paris, 199 pp

Vivian R (2001) Des glacières du Faucigny aux glaciers du Mont-Blanc. La Fontaine de Siloé, Montmélian, $296 \mathrm{pp}$

Wanner H, Holzhauser H, Pfister C, Zumbühl HJ (2000) Interannual to century scale climate variability in the European Alps. Erdkunde 54(1):62-69

Wanner H, Luterbacher J, Casty C, Böhm R, Xoplaki E (2003) Variabilität von Temperatur und Niederschlag in den europäischen Alpen seit 1500. In: Jeanneret F, Wastl-Walter D, Wiesmann U, Schwyn M (eds) Welt der Alpen-Gebirge der Welt. Ressourcen, Akteure, Perspektiven. Jahrbuch der Geographischen Gesellschaft Bern, Band 61. Haupt, Bern/Stuttgart/Wien, pp 61-76

Wanner H, Beer J, Bütikofer J, Crowley TJ, Cubasch U, Flückiger J, Goosse H, Grosjean M, Joos F, Kaplan JO, Küttel M, Müller SA, Prentice IC, Solomina O, Stocker TF, Tarasov P, Wagner M, Widmann M (2008) Mid- to Late Holocene climate change: an overview. Quat Sci Rev 27(19-20):1791-1828

Wetter W (1987) Spät-und postglaziale Gletscherschwankungen im Mont Blanc-Gebiet: Untere Vallée de Chamonix-Val Montjoie. Physische Geographie, vol 22. Geographisches Institut der Universität Zürich, Zürich, $267 \mathrm{pp}$

Wilton A (1979) William Pars. Journey through the Alps-Reise durch die Alpen-Voyages dans les Alpes. De Clivo Press, Dübendorf (Zürich), 71 pp

Zemp M, Haeberli W, Hoelzle M, Paul F (2006) Alpine glaciers to disappear within decades? Geophys Res Lett 33(13):L13504. doi:10.1029/2006GL026319

Zumbühl HJ (1980) Die Schwankungen der Grindelwaldgletscher in den historischen Bild- und Schriftquellen des 12. bis 19. Jahrhunderts. Ein Beitrag zur Gletschergeschichte und Erforschung des Alpenraumes. Denkschriften der Schweizerischen Naturforschenden Gesellschaft (SNG), Band 92. Birkhäuser, Basel/Boston/Stuttgart, 279 pp

Zumbühl HJ, Holzhauser H (1988) Alpengletscher in der Kleinen Eiszeit. Sonderheft zum 125jährigen Jubiläum des SAC. Alpen 64(3):129-322

Zumbühl HJ, Messerli B, Pfister C (1983) Die Kleine Eiszeit: Gletschergeschichte im Spiegel der Kunst. Katalog zur Sonderausstellung des Schweizerischen Alpinen Museums Bern und des Gletschergarten-Museums Luzern vom 09.06.-14.08.1983 (Luzern), 24.08.-16.10.1983 (Bern), $60 \mathrm{pp}$

Zumbühl HJ, Steiner D, Nussbaumer SU (2008) 19th century glacier representations and fluctuations in the central and western European Alps: an interdisciplinary approach. Glob Planet Change 60(1-2):42-57 